\title{
Continuous Partial Oxidation of Methane to Methanol Catalyzed by Diffusion-Paired Cu Dimers in Copper-Exchanged Zeolites
}

Kimberly T. Dinh ${ }^{\dagger}$, Mark M. Sullivan ${ }^{\dagger}$, Karthik Narsimhan ${ }^{\dagger}$, Pedro Serna ${ }^{ \pm}$, Randall J. Meyer $^{ \pm}$, Mircea Dincă ${ }^{\ddagger}$, Yuriy Román-Leshkov ${ }^{\text {t* }}$

tDepartment of Chemical Engineering, Massachusetts Institute of Technology, 77 Massachusetts Avenue, Cambridge, Massachusetts 02139, United States

士ExxonMobil Research and Engineering, Annandale, New Jersey 08801, United States

施epartment of Chemistry, Massachusetts Institute of Technology, 77 Massachusetts Avenue, Cambridge, Massachusetts 02139, United States

§These authors contributed equally

\section{Table of Contents}

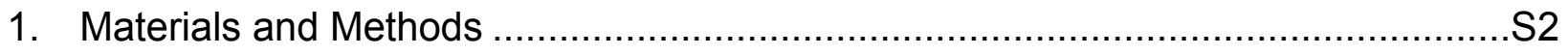

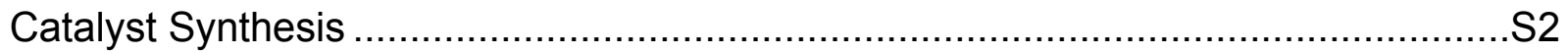

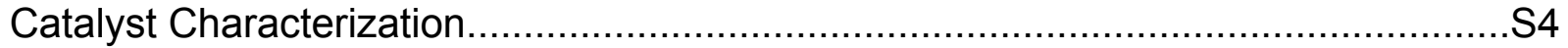

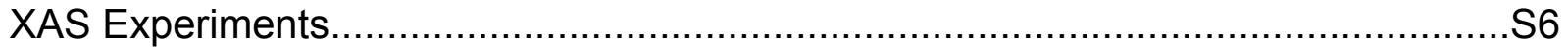

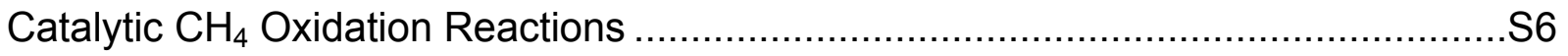

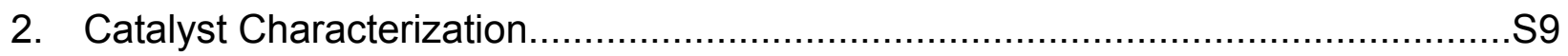

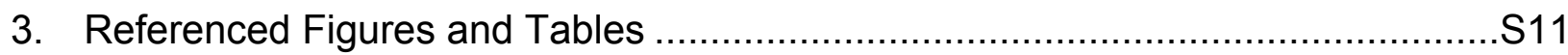




\section{Materials and Methods}

\section{Catalyst Synthesis}

Synthesis of $\mathrm{H}-\mathrm{CHA}(\mathrm{Si} / \mathrm{Al}=8.8)$

To $22.7 \mathrm{~g}$ of colloidal silicon dioxide (Ludox® LS-30), $1.1 \mathrm{~g}$ of aluminum hydroxide (80.3 wt $\% \mathrm{Al}(\mathrm{OH})_{3}$, SPI Pharma 0250) was dissolved. Following, $6.0 \mathrm{~g}$ of aqueous sodium

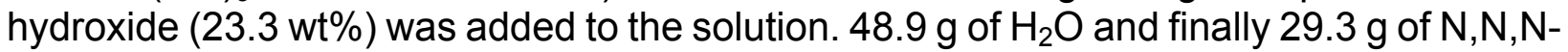
trimethyl-1-adamantanamine hydroxide solution (TMAdaOH, 25 wt $\%$ in $\mathrm{H}_{2} \mathrm{O}$, Sachem) were added. The final composition of the solution was $1 \mathrm{SiO}_{2}: 0.1 \mathrm{Al}(\mathrm{OH})_{3}: 0.3 \mathrm{NaOH}: 0.3$ TMAdaOH: $45 \mathrm{H}_{2} \mathrm{O}$. The solution was stirred at room temperature for $6 \mathrm{~h}$, transferred to six 23-mL Teflon-lined stainless steel autoclaves (No. 4749, Parr Instruments) and subjected to hydrothermal treatment at $433 \mathrm{~K}$ for 5 days in an oven under autogenous pressure and rotation $(60 \mathrm{rpm})$. After hydrothermal treatment, the product was separated from the mother liquor by centrifugation, washed several times with distilled $\mathrm{H}_{2} \mathrm{O}$ and dried at $393 \mathrm{~K}$. The zeolite was calcined under dry air (Dry Size 300, Airgas) with the following temperature profile: heat $1 \mathrm{~K} \mathrm{~min}^{-1}$ to $423 \mathrm{~K}$ and hold for $1 \mathrm{~h}$ at $423 \mathrm{~K}$, heat $1 \mathrm{~K} \mathrm{~min}^{-1}$ to $623 \mathrm{~K}$ and hold for $1 \mathrm{~h}$ at $623 \mathrm{~K}$, and lastly heat $1 \mathrm{~K} \mathrm{~min}^{-1}$ to $853 \mathrm{~K}$ and hold for $10 \mathrm{~h}$.

\section{Ammonium exchange}

To remove $\mathrm{Na}$ from the synthesized SSZ-13 catalyst, $1 \mathrm{~g}$ of zeolite was stirred in $60 \mathrm{~mL}$ of a $1.0 \mathrm{M}$ solution of ammonium nitrate ( $\geq 99 \%$, Sigma-Aldrich) for $16 \mathrm{~h}$ at room temperature. The suspension was filtered at room temperature, rinsed with $300 \mathrm{~mL}$ of deionized $\mathrm{H}_{2} \mathrm{O}$, and the recovered zeolite was immediately subjected to a second ion exchange under the same conditions. Following, the zeolite was dried overnight at $393 \mathrm{~K}$ in stagnant air and calcined following the same profile described above.

\section{Copper exchange}

$1 \mathrm{~g}$ of zeolite was stirred in $150 \mathrm{~mL}$ of $0.0005-0.05 \mathrm{M}$ solutions of copper (II) acetate monohydrate (>99\%, Sigma-Aldrich) at room temperature for between one to two days. The suspension was then either filtered at room temperature and rinsed with $400 \mathrm{~mL}$ of deionized $\mathrm{H}_{2} \mathrm{O}$ or recovered and washed via centrifugation. The zeolite was dried overnight at $393 \mathrm{~K}$ in a drying oven and subsequently calcined using the same procedure as described above. If needed, some catalysts were subjected to one to two additional $\mathrm{Cu}$ exchanges to achieve a targeted Cu loading. 
Synthesis of 1-6MR Cu-SSZ-13

1-Al Cu-SSZ-13 was synthesized in a similar manner as $\mathrm{H}-\mathrm{CHA}$ and is a modification of the works of Di lorio et al. ${ }^{1}$ and Martinez-Franco et al. ${ }^{2}$ One-pot methods have been reported for the synthesis for Cu-SSZ-13 via the use of tetraethylenepentamine (TEPA). ${ }^{3}$ TEPA acts as both a structure-directing agent and a chelating agent for $\mathrm{Cu}$. Simulations have demonstrated that Cu-TEPA localizes one $\mathrm{Cu}$ per cage. ${ }^{3}$ However, reported syntheses indicate a prevalence of copper oxides due to the amount of $\mathrm{Cu}$ incorporated into the zeolite when TEPA is used. To limit the presence of copper oxides, we utilized a cooperative SDA synthesis method; - $\mathrm{OH}$ and TMAdaOH content was maintained constant and $\mathrm{Cu}$ content was controlled by $\mathrm{Cu}^{2+}$ loading in the synthesis gel. TEPA was added in $10 \%$ excess of the stoichiometric quantity $\left(1 \mathrm{TEPA}: 1 \mathrm{Cu}^{2+}\right)$. To obtain a catalyst with only isolated $\mathrm{Al}$, synthesis gels were entirely devoid of $\mathrm{Na}^{+}$and ionic charge was instead balanced with TMAda ${ }^{+}$. The combination of these methods affords control over the fraction of paired framework $\mathrm{Al}$ and zeolite composition (Al, $\mathrm{Na}$, and $\mathrm{Cu}$ contents) in a one-step method without the need for additional metal incorporation via ion exchange. Si/Al ratios between 10 and 25 were attainable with $\mathrm{Cu}$ loadings ranging from 0 to 0.60 .

Copper sulfate pentahydrate ( $98 \%$ trace metals basis, Sigma-Aldrich) was first dissolved in water followed by the addition of tetraethylenepentamine (TEPA, technical grade, Sigma-Aldrich) and stirred for an hour before the addition of TMAdaOH. Following, aluminum hydroxide was dissolved in the solution before fumed silica (Sigma-Aldrich, $99.8 \%$ ) was added. The final composition of the mixture was $1 \mathrm{SiO}_{2}: x \mathrm{Al}(\mathrm{OH})_{3}: 0.4$ TMAdaOH: $44 \mathrm{H}_{2} \mathrm{O}: z \mathrm{CuSO}_{4}$ : $1.1 z$ TEPA where $0.1 \leq x \leq 0.03$ and $0 \leq z \leq 0.6$. The solution was subjected to the same aging, thermal, purification and calcination treatments as described for $\mathrm{H}-\mathrm{CHA}$.

Synthesis of $\mathrm{Na}-\mathrm{Cu}-\mathrm{CHA}(0.12)$

$\mathrm{Na}-\mathrm{Cu}-\mathrm{CHA}(26,0.27)$ was synthesized in the same manner as the 1-6MR Cu-SSZ-13 samples except $\mathrm{NaOH}$ was added to the solution following addition of TMAdaOH. The final composition of the mixture was $1 \mathrm{SiO}_{2}: 0.03 \mathrm{Al}(\mathrm{OH})_{3}: 0.2 \mathrm{NaOH}: 0.2 \mathrm{TMAdaOH}: 44$ $\mathrm{H}_{2} \mathrm{O}: 0.01 \mathrm{CuSO}_{4}: 0.011$ TEPA.

Synthesis of $1 \mathrm{Al}-\mathrm{Cu}-\mathrm{CHA}$

1Al-Cu-CHA was synthesized based on the work of Eilertsen, et al. ${ }^{4}$ Briefly, copper sulfate pentahydrate, TEPA, and TMAdaOH were stirred for $30 \mathrm{~min}$ in a PTFE jar. Following, aluminum hydroxide was added to the solution and stirred until the solution was clear. In a separate container, ethanol (200 proof, Koptec) and tetraethylorthosilicate $(>99.0 \%$ (GC), Sigma-Aldrich) were stirred uncovered for $30 \mathrm{~min}$. The ethanol and tetraethylorthosilicate solution was added to the copper solution and stirred uncovered until the target water ratio was obtained. Hydrofluoric acid (48 wt $\%$ in $\mathrm{H}_{2} \mathrm{O},>99.99 \%$ trace metals basis, Sigma-Aldrich) was then added and the gel was homogenized by hand. Caution: HF Use proper personal protective equipment, ventilation, and additional safety measures. The final composition of the mixture was $100 \mathrm{SiO}_{2}: 1.33 \mathrm{Al}(\mathrm{OH})_{3}: 50$ TMAdaOH: $300 \mathrm{H}_{2} \mathrm{O}: 50 \mathrm{HF}: 0.51 \mathrm{CuSO}_{4}$ : 0.56 TEPA. The gel was transferred to a 23$\mathrm{mL}$ Teflon-lined stainless steel autoclave and subjected to hydrothermal treatment at 428 
$\mathrm{K}$ for $40 \mathrm{~h}$ in an oven under autogenous pressure and rotation (60 rpm). The zeolite was subjected to the same purification and calcination treatments as described for $\mathrm{H}-\mathrm{CHA}$.

Synthesis of $\mathrm{Cu}_{x} \mathrm{O}_{y}$ in defect-free SSZ-13 (0AI-Cu-CHA)

Defect-free SSZ-13 was synthesized according to the method of Díaz-Cabañas et al. ${ }^{5}$ Copper (II) nitrate trihydrate (Sigma-Aldrich, puriss. p.a., 99-104\%) was incorporated into the zeolite via incipient wetness impregnation to achieve a $1 \mathrm{wt} \% \mathrm{Cu}$ loading. To 0.5 of defect-free SSZ-13, $0.29 \mathrm{~g}$ of $0.27 \mathrm{M} \mathrm{Cu}\left(\mathrm{NO}_{3}\right)_{2} \cdot 3 \mathrm{H}_{2} \mathrm{O}$ (aq) was added dropwise. The catalyst was calcined with the same temperature profile as previously described.

\section{Catalyst Characterization}

\section{Elemental analysis}

Copper, sodium and aluminum contents were determined using inductively coupled plasma atomic emission spectroscopy (ICP-AES, Agilent 5100) or inductively coupled plasma mass spectrometry (ICP-MS, Agilent 7900). 5-10 mg of zeolite were placed in a polyethylene microfuge tube $(1.5 \mathrm{~mL}$ ) and digested in $20 \mu \mathrm{L}$ hydrofluoric acid (48 wt \%, trace metals basis, Sigma-Aldrich) for $2 \mathrm{~h}$. The hydrofluoric acid solution was diluted to a total mass of $10.0 \mathrm{~g}$ using $2 \mathrm{wt} \%$ aqueous nitric acid $\left(\mathrm{HNO}_{3}\right)$ (veritas purity, GFS Chemicals). When using ICP-MS, $1 \mathrm{~mL}$ of these solutions were diluted once more to 10 $\mathrm{mL}$ solution total. A six point calibration curve was built using ICP standard solutions of $1,000 \mathrm{ppm} \mathrm{Cu}$ in $2 \mathrm{wt} \% \mathrm{HNO}_{3}, 1,000 \mathrm{ppm} \mathrm{Al}$ in $2 \mathrm{wt} \% \mathrm{HNO}_{3}$ and $1,000 \mathrm{ppm} \mathrm{Na}$ in $2 \mathrm{wt} \%$ $\mathrm{HNO}_{3}$. All standard solutions were purchased from Sigma-Aldrich (TraceCERT).

Calculations of molar ratios Si/Al tot and $\mathrm{Cu} / \mathrm{Al}_{\text {tot }}$.

The unit cell of a zeolite is given by:

$$
\mathrm{H}_{x}^{+} \mathrm{Na}_{y}^{+} \mathrm{Cu}_{z}^{2+}\left(\mathrm{AlO}_{2}\right)_{n}^{-}\left(\mathrm{SiO}_{2}\right)_{m}\left(\mathrm{H}_{2} \mathrm{O}\right)_{k}
$$

where subscripts refer to the molar ratios of each component within the unit cell of a zeolite. Local charge balance was assumed to occur within the zeolite, requiring $x=n-2 z-y$.

From the unit cell given above, the mass balance of the unit cell is given by the following equation on a per gram zeolite basis:

$$
1=a \frac{g \mathrm{SiO}_{2}}{g \text { zeolite }}+b \frac{g\left[\mathrm{AlO}_{2}\right]^{-}}{\text {g zeolite }}+c \frac{g \mathrm{Cu}^{2+}}{g \text { zeolite }}+d \frac{g \mathrm{Na}^{+}}{g \text { zeolite }}+e \frac{g \mathrm{H}^{+}}{g \text { zeolite }}+f \frac{g \mathrm{H}_{2} \mathrm{O}}{\text { g zeolite }}
$$

where each coefficient represents the weight percent of each species. The weight percent of $\mathrm{Al}, \mathrm{Cu}$ and Na were directly calculated using ICP-AES, allowing $b, c$, and $d$ to be determined. Converting the weight percentages of $\mathrm{Al}, \mathrm{Cu}$ and $\mathrm{Na}$ to mole percentages per gram zeolite, $e$ was then calculated using the local charge balance of cations on the zeolite framework. The weight percentage of $\mathrm{H}_{2} \mathrm{O}(f)$ was assumed to be equal to the weight percentage of $\mathrm{H}_{2} \mathrm{O}$ in the zeolite framework unit cell $(2-7 \mathrm{wt} \%){ }^{6}$ The mass balance was then solved for the weight percentage of $\mathrm{SiO}_{2}(a)$. 
$\mathrm{Si} / \mathrm{Al}_{\text {tot }}$ was calculated by $\frac{\mathrm{Si}}{\mathrm{Al}_{\mathrm{tot}}}=\frac{a m_{\mathrm{AlO} 2}}{b m_{\mathrm{SiO} 2}} \times \frac{1 \mathrm{~mol} \mathrm{Si}}{1 \mathrm{~mol} \mathrm{SiO}_{2}} \times \frac{1 \mathrm{~mol} \mathrm{AlO}}{2 \mathrm{~mol} \mathrm{Al}}$

where $m_{i}$ is the molar mass of element $i$.

$\mathrm{Cu} / \mathrm{Al} \mathrm{I}_{\text {tot }}$ was calculated by $\frac{\mathrm{Cu}}{\mathrm{Al} l_{\text {tot }}}=\frac{\mathrm{cm}_{\mathrm{AlO2}}}{\mathrm{b} \mathrm{m}_{\mathrm{Cu}}} \times \frac{1 \mathrm{~mol} \mathrm{AlO}}{1 \mathrm{~mol} \mathrm{Al}}$

\section{Powder X-Ray Diffraction}

The crystal structures of zeolite catalysts were determined from powder $x$-ray diffraction patterns collected using a Bruker D8 diffractometer using Cu-Ka radiation $(\lambda=1.5418 \AA$, $40 \mathrm{kV}, 40 \mathrm{~mA}$ ). Data were recorded in the range of 3-40 $2 \theta$ with an angular step size of $0.02^{\circ}$ and a rate of $4^{\circ} \mathrm{min}^{-1}$.

\section{UV-Vis-NIR Spectroscopy}

UV-Vis-NIR spectroscopy was performed on a Cary 5000 UV-Vis-NIR spectrometer (Agilent Technologies) equipped with a DiffusIR diffuse reflectance accessory (PIKE Technologies). Gas phase flow conditions and temperature were maintained to mimic those obtained during steady state catalysis: $\mathrm{T}=543 \mathrm{~K}$, ambient pressure, $0.09 \mathrm{kPa} \mathrm{O}, 3$ $\mathrm{kPa} \mathrm{H} \mathrm{H}_{2} \mathrm{O}, 18 \mathrm{kPa} \mathrm{CH}_{4}$, balance Helium, total flow of $25 \mathrm{sccm}$. Absolute reflectance was measured at ambient conditions from $11,100 \mathrm{~cm}^{-1}$ to $52,600 \mathrm{~cm}^{-1}$ with a scan rate of $11,700 \mathrm{~cm}^{-1} \mathrm{~min}^{-1}$. All spectra were normalized with respect to a background spectra of hydrated H-SSZ-13 (Si/Al = 8.8).

\section{IR Spectroscopy}

Infrared spectroscopic measurements were collected using a Vertex 80 spectrometer (Bruker Instruments) equipped with a liquid nitrogen cooled mercury-cadmium-telluride detector. Experiments were performed in a high temperature reaction cell for transmission acquisition (HTC-3, Harrick Scientific). $10 \mathrm{mg}$ of a zeolite sample was pressed into a $0.7 \mathrm{~cm}$ diameter wafer. All spectra were collected under flowing He (ultrahigh purity, Airgas) unless otherwise noted. All spectra were collected at $4 \mathrm{~cm}^{-1}$ resolution, averaged over 256 scans, and baseline corrected.

\section{Surface Area and Pore Volume Quantification}

Nitrogen adsorption and desorption isotherms were measured on a Quantachrome Autosorb $\mathrm{iQ}$ apparatus at liquid nitrogen temperature $(77 \mathrm{~K})$. Prior to the adsorption analysis, all samples were degassed under vacuum for $12 \mathrm{~h}$ at $623 \mathrm{~K}$. Micropore volume was calculated using the t-plot method.

\section{X-ray Absorption Spectroscopy}

XAS experiments were carried out on the bending magnet beamline of Sectors 9 and 10 MRCAT at the Advanced Photon Source (APS) at Argonne National Laboratory. A cryogenically cooled double-crystal $\mathrm{Si}(111)$ monochromator was used with an uncoated glass mirror to minimize the presence of harmonics. Spectra were recorded in transmission mode with the ionization chambers optimized for the maximum current with linear response using gas mixtures to give $10 \%$ absorption in the incident $\mathrm{X}$-ray detector 
(6\% $\mathrm{He}$ in $\mathrm{N}_{2}$ ) and $70 \%$ absorption in the transmission X-ray detector $\left(42 \% \mathrm{Ar}\right.$ in $\left.\mathrm{N}_{2}\right)$. A Cu metal foil spectrum was simultaneously collected while measuring sample spectra to calibrate the Cu K-edge to $8979 \mathrm{eV}$. XANES and EXAFS spectra were collected while the catalyst was exposed to the various gas treatments. For each treatment, the data were averaged over three spectra.

\section{XAS Experiments}

Cu-CHA(0.11) was ground into a fine powder, and a loaded in a custom in situ fluorescence cell capable of gas flows and temperature control. In a separate experiment, $\mathrm{Cu}-\mathrm{CHA}(0.11)$ and 1-Al-Cu-CHA were analyzed in transmission via a six shooter placed in a quartz tube inside a clamshell furnace equipped with a temperature controller.

EXAFS spectra were collected before heating under ambient conditions. Catalysts were calcined with $50 \mathrm{sccm} 1 \% \mathrm{O}_{2}$ in $\mathrm{He}$ from ambient conditions to $543 \mathrm{~K}$ with a ramp of $5 \mathrm{~K}$ $\min ^{-1}$ and XAS was collected. Methanol synthesis flows of $100 \mathrm{sccm} \mathrm{P}_{\mathrm{CH} 4}=18 \mathrm{kPa}, \mathrm{P}_{\mathrm{O} 2}$ $=0.09 \mathrm{kPa}, \mathrm{P}_{\mathrm{H} 2 \mathrm{O}}=3.14 \mathrm{kPa}$, bal He were introduced, followed by a $1.6 \mathrm{kPa} \mathrm{NH} \mathrm{N}_{3} \mathrm{co}$-feed and an equimolar removal of $\mathrm{He}$ to maintain a $100 \mathrm{sccm}$ total flow. $\mathrm{NH} 3$ was removed and the gas flow was made up with $\mathrm{He}$. Following $\mathrm{NH}_{3}$ removal, the catalyst was brought to $673 \mathrm{~K}$ at $6 \mathrm{~K} \mathrm{~min}^{-1}$ and held in $100 \mathrm{sccm}$ dry He before cooling to $543 \mathrm{~K}$ and exposure to methanol synthesis flows. XANES ( $4.5 \mathrm{~min} / \mathrm{scan})$ were collected at each stage until no change in spectra were observed. Following, EXAFS was performed. All spectra were collected at $543 \mathrm{~K}$.

\section{XAS Data Fitting}

XAS data was processed and fitted using the Athena and Artemis software from the Demeter package. Spectra were normalized using third-order polynomials in both the preand post-edge regions and were calibrated using the first zero-crossing of the second derivative of the Cu metal foil spectrum. EXAFS data were fit from $\mathrm{k}=3$ to $\sim 8.5 \AA^{-1}$ and $\mathrm{R}=1-3.2 \AA$ with a Hanning window and $\mathrm{dk}=2$, unless otherwise noted. Reported uncertainties are taken from the diagonal of the covariance matrix and scaled by $\sqrt{X^{2}} v$

\section{Catalytic $\mathrm{CH}_{4}$ Oxidation Reactions}

$\mathrm{CH}_{4}$ oxidation reactions were conducted in a continuous, tubular flow reactor (stainless steel tube, O.D. $6.35 \mathrm{~mm}$, I.D. $4.57 \mathrm{~mm}$ ). The reactor tube was mounted inside of a single-zone furnace (850W / 115V, Applied Test Systems Series 3210). Temperature was controlled using a thermocouple (Omega, model TJ36-CASS-116U) mounted slightly downstream of the catalyst bed connected to a temperature controller (Digi-Sense model $68900-10) .0 .25 \mathrm{~g}$ of zeolite particles (pelletized and sieved into 250-420 $\mu \mathrm{m}$ particles) were packed between quartz wool plugs and rested on the thermocouple in the middle of the furnace heating zone. Void volume above and below the catalyst bed was filled with borosilicate glass beads to reduce homogeneous combustion. The flow of gases, including $\mathrm{He}$ (ultra high purity, Airgas), $1 \% \mathrm{O}_{2}$ in $\mathrm{He}$ (ultra high purity, Airgas), and $\mathrm{CH}_{4}$ (research grade, Airgas) were controlled with independent mass flow controllers (Brooks 
Instruments LLC). $\mathrm{H}_{2} \mathrm{O}$ (typically $3.2 \mathrm{kPa}$ ) was introduced into the gas stream using a syringe pump with a heated liquid injection port. Stainless steel gas transfer lines were heated with resistive heating tape from the point of liquid injection until the gas chromatographic analysis unit. Typical reaction pretreatment involved heating under $\sim 50$

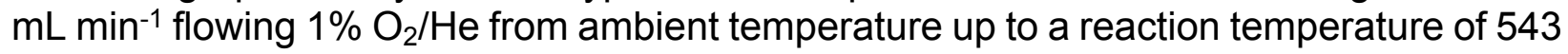
$\mathrm{K}$ unless otherwise specified.

$\mathrm{CH}_{3} \mathrm{OH}$, dimethyl ether (DME), $\mathrm{CO}_{2}$, and alkane partial pressures evolved during catalytic $\mathrm{CH}_{4}$ oxidation were quantified using a gas chromatograph (Agilent Technologies, 7890B). The gas chromatograph was equipped with a methanizer, flame ionization detector, and thermal conductivity detector. Three columns were used for product separation: two HPPLOT Q PT (30 m x $0.53 \mathrm{~mm} \times 40 \mu \mathrm{m}$, Agilent \#19095P-QO4PT) and HP PLOT Molsieve (30 m x $0.53 \mathrm{~mm} \times 50 \mu \mathrm{m}$, Agilent \#19095P-MS0E).

Once steady-state $\mathrm{CH}_{3} \mathrm{OH}$ production was achieved at $543 \mathrm{~K}$, kinetic experiments were conducted. Contact time variations were performed by proportional alterations of all gas and liquid flow rates in order to maintain contact gas phase partial pressures. Titration experiments were performed by additional flow of $1 \% \mathrm{NH}_{3} / \mathrm{He}$ (ultra high purity, Airgas) and simultaneous removal of an equimolar flow of helium to maintain a constant space velocity. All reported values for selectivity, rates of product formation, and site time yield were averaged over three data points upon reaching steady-state.

Product quantification

Calibration curves for $\mathrm{CH}_{3} \mathrm{OH}$ were constructed using a known vapor pressure of $\mathrm{CH}_{3} \mathrm{OH}$ taken into a $\mathrm{CH}_{4}$ stream. $\mathrm{CH}_{3} \mathrm{OH}$ vapor pressure was controlled by immersing the saturator containing $\mathrm{CH}_{3} \mathrm{OH}$ into cooling baths at several temperatures (e.g. ice water at $273 \mathrm{~K}$, dry ice in ethanol at $201 \mathrm{~K}$, etc). Relative response factors were calculated using the gas chromatograph between known $\mathrm{CH}_{4}$ and $\mathrm{CH}_{3} \mathrm{OH}$ partial pressures. Calibration curves for $\mathrm{CO}_{2}$ and DME were constructed by flowing known mixtures of $1 \% \mathrm{CO}_{2} / \mathrm{He}$ or $10 \% \mathrm{DME} / \mathrm{He}$ and He to a gas chromatograph.

The large partial pressure of $\mathrm{CH}_{4}$ in the gas stream during catalytic $\mathrm{CH}_{4}$ oxidation reactions prevented the accurate quantification of $\mathrm{CH}_{4}$ consumption. As such, $\mathrm{CH}_{4}$ conversion was assumed to be equal to the total molar flow rate of carbon of all observed products divided by the initial molar flow rate of $\mathrm{CH}_{4}$ :

$$
X_{C H 4}=\frac{\sum_{i=1}^{N} C_{i} F_{i}}{F_{C H 4,0}}
$$

where $X_{\mathrm{CH}_{4}}$ is the conversion of $\mathrm{CH}_{4}, F_{\mathrm{i}}$ is the molar flow rate of product $i, C_{\mathrm{i}}$ is the number of carbon atoms in product $i, \Sigma C_{\mathrm{i}} F_{\mathrm{i}}$ is the total molar flow rate of carbon of all products, and $F_{\mathrm{CH} 4,0}$ is the initial molar flow rate of $\mathrm{CH}_{4}$.

Product selectivity for catalytic $\mathrm{CH}_{4}$ oxidation was defined as:

$$
S_{i}=\frac{C_{i} F_{i}}{\sum_{i=1}^{N} C_{i} F_{i}}
$$


where $S_{\mathrm{i}}$ is the selectivity of product $i$ on a $C$-atom basis, $C_{\mathrm{i}}$ is the number of carbon atoms in product $i, F_{\mathrm{i}}$ is the molar flow rate of product $i$, and $\Sigma C_{i} F_{\mathrm{i}}$ is the total molar flow rate of carbon of all products.

Site-time yield (STY) for catalytic $\mathrm{CH}_{4}$ oxidation was defined as:

$$
S T Y=\frac{\sum_{i=1}^{N} C_{i} F_{i}}{N_{C u}}
$$

where $N_{C u}$ is the number of moles of $\mathrm{Cu}$ within the zeolite determined by ICP. 


\section{Catalyst Characterization}

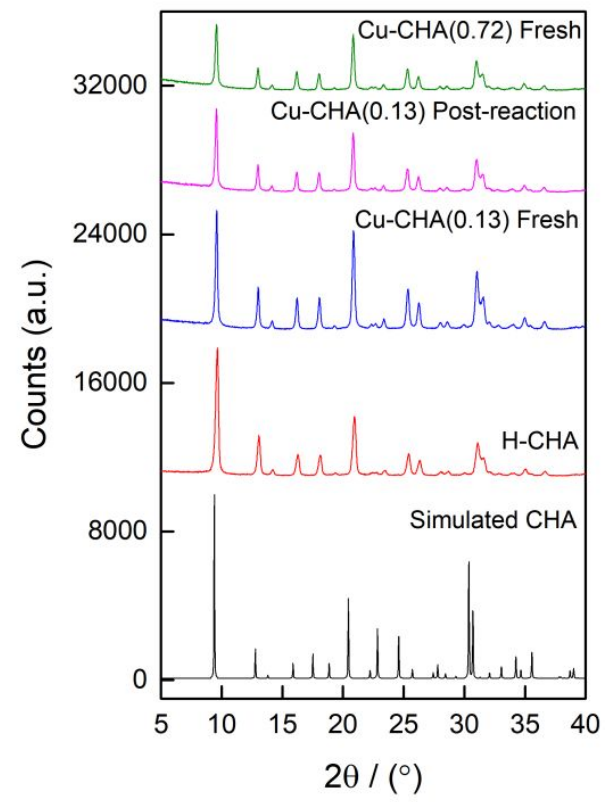

Figure 1-1. Powder x-ray diffraction of as-synthesized and post-reaction catalysts. Catalysts displayed expected reflections of $\mathrm{CHA}$ and no loss in crystallinity was observed following exposure to methanol synthesis flows.

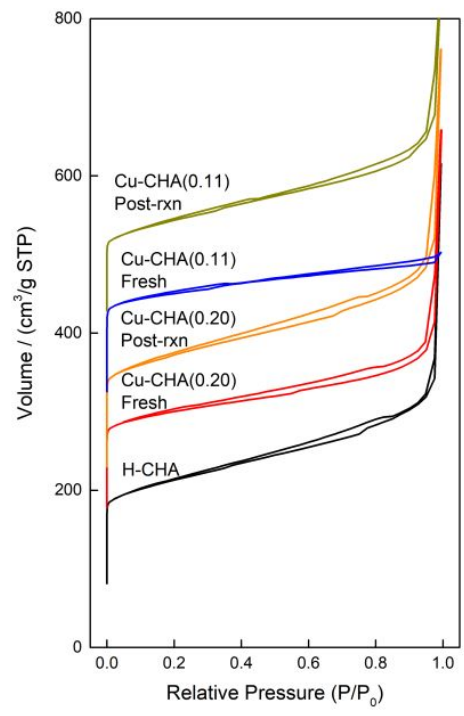

Figure 1-2. $\mathrm{N}_{2}$ physisorption isotherms of as-synthesized and post-reaction catalysts. 
Table 1-1. Micropore volumes of as-synthesized and post-reaction catalysts, calculated using t-plot method.

\begin{tabular}{cc}
\hline Catalyst & Micropore volume $\left(\mathbf{c m}^{3} \mathbf{g}\right)$ \\
\hline $\begin{array}{c}\text { Cu-CHA(0.11) } \\
\text { Post-reaction } \\
\text { Cu-CHA(0.11) } \\
\text { Fresh }\end{array}$ & 0.20 \\
$\begin{array}{c}\text { Cu-CHA(0.20) } \\
\text { Post-reaction } \\
\text { Cu-CHA(0.20) } \\
\text { Fresh } \\
\text { H-CHA }\end{array}$ & 0.23 \\
\hline
\end{tabular}




\section{Referenced Figures and Tables}

Kinetic experiments were performed in the absence of heat or mass transfer limitations (Figure S1 and Table S1). Under typical reaction conditions, the steady state production of methanol was extremely stable with $\mathrm{CH}_{4}$ conversion values below $0.1 \%$ with no observable deactivation over the course of $100 \mathrm{~h}$ on stream (Figure S2). Methane conversion was negligible when exposing a non-Cu exchanged, Brønsted acid form $\mathrm{H}$ SSZ-13 catalyst to typical reaction conditions. $\mathrm{O}_{2}$ conversion was typically $<10 \%$. Quantifiable products consisted primarily of methanol, $\mathrm{CO}_{2}$, and dimethyl ether (DME). $\mathrm{CO}$ and ethylene were observed as minor products under some higher temperature reaction conditions. Homogeneous combustion was measured in a blank reactor and accounted for $<5 \%$ of all products formed (Figure S3).

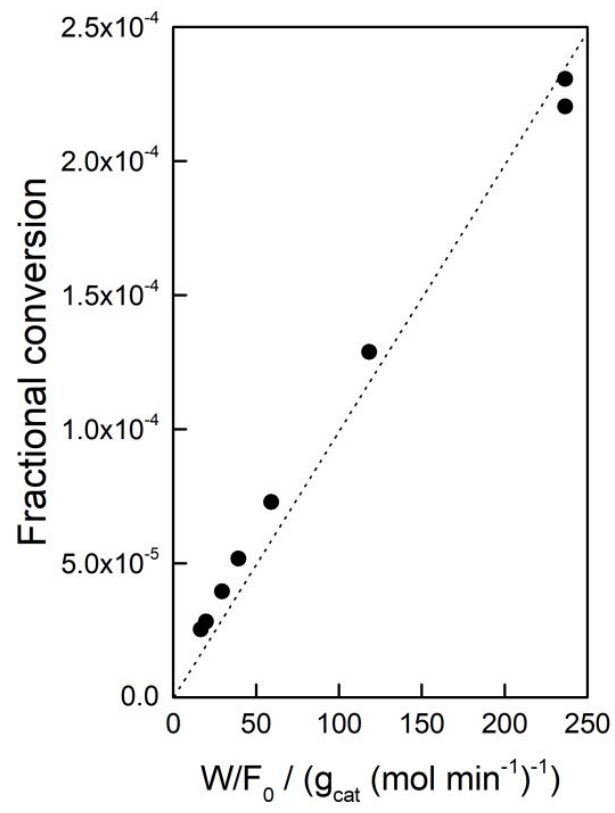

Figure S1. Fractional conversion versus contact time. Linear relation demonstrates absence of heat and mass transfer limitations. Cu-CHA(0.11), $0.25 \mathrm{~g}_{\text {cat }}, 543 \mathrm{~K}, 25-200$ sccm, $\mathrm{P}_{\mathrm{CH} 4}=18 \mathrm{kPa}, \mathrm{P}_{\mathrm{O} 2}=0.09 \mathrm{kPa}, \mathrm{P}_{\mathrm{H} 2 \mathrm{O}}=3.14 \mathrm{kPa}$, bal He. 
Table S1. Parameters used for verification of absence of heat and mass transfer gradients. GradientCheck for Heterogeneous Catalysis was used. ${ }^{7}$ Gaseous properties were obtained from the NIST WebBook's Thermophysical Properties of Fluid Systems. ${ }^{8}$

\begin{tabular}{cc}
\hline $\begin{array}{c}\operatorname{max~r}_{\mathrm{obs}} \\
\left(\mathrm{mol} \mathrm{kg}_{\left.\mathrm{cat}^{-1} \mathrm{~s}^{-1}\right)}\right.\end{array}$ & $7.24 \cdot 10^{-6}$ \\
$\begin{array}{c}\Delta \mathrm{H}_{\mathrm{rxn}} \\
\left(\mathrm{KJ} \mathrm{mol}^{-1}\right)\end{array}$ & -127 \\
$\begin{array}{c}\mathrm{E}_{\mathrm{a}} \\
\left(\mathrm{kJ} \mathrm{mol}^{-1}\right)\end{array}$ & 100 \\
$\begin{array}{c}\text { Fractional } \\
\text { conversion }\end{array}$ & 0.001 \\
$\mathrm{n}$ & 1 \\
$\begin{array}{c}\rho_{\text {bulk }}\left(\mathrm{kg} \mathrm{m}^{-3}\right) \\
(\text { Assumed } \varepsilon=0.4)\end{array}$ & 750 \\
\hline
\end{tabular}




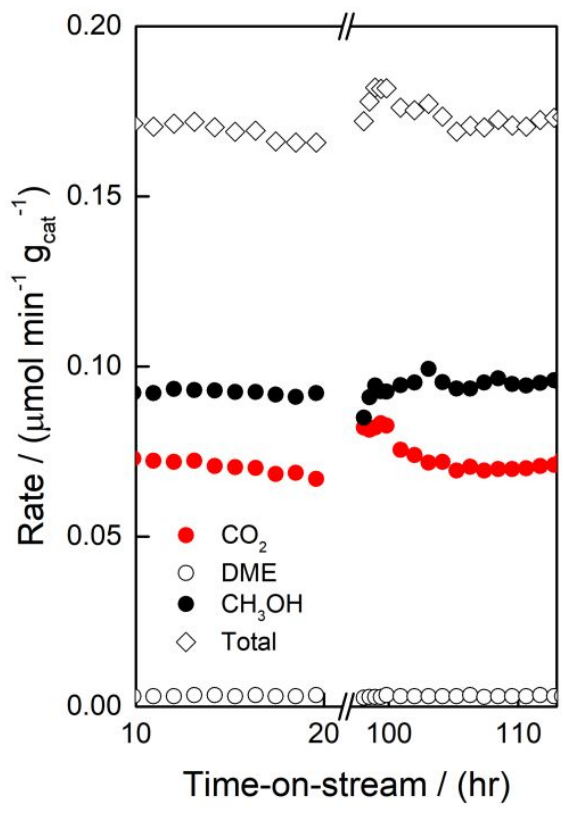

Figure S2. Product formation rates versus time-on-stream, demonstrating catalyst stability for $>4$ days on stream. Cu-CHA(0.11), $0.25 \mathrm{~g}$ cat, $543 \mathrm{~K}, 25 \mathrm{sccm}, \mathrm{P}_{\mathrm{CH} 4}=18 \mathrm{kPa}$, $\mathrm{P}_{\mathrm{O} 2}=0.09 \mathrm{kPa}, \mathrm{P}_{\mathrm{H} 2 \mathrm{O}}=3.14 \mathrm{kPa}$, bal He.

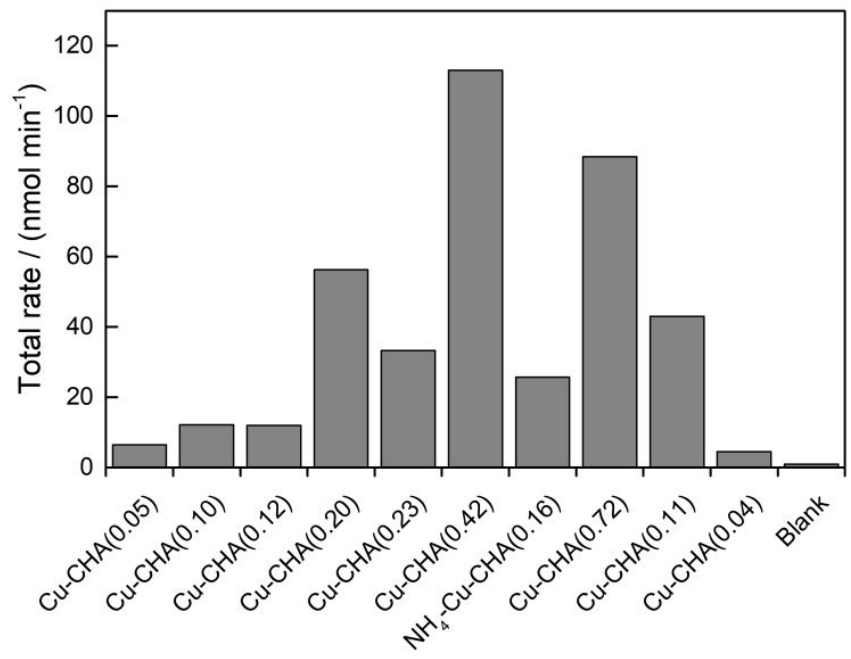

Figure S3. Total rates of $\mathrm{C}-\mathrm{H}$ scission calculated as the carbon-weighted sum of all reaction products at steady state. Total flow of $25 \mathrm{sccm}, \mathrm{P}_{\mathrm{CH} 4}=18 \mathrm{kPa}, \mathrm{P}_{\mathrm{O} 2}=0.09 \mathrm{kPa}$, $\mathrm{P}_{\mathrm{H} 2 \mathrm{O}}=3.14 \mathrm{kPa}$, bal He. $\mathrm{T}=543 \mathrm{~K}, 0.25 \mathrm{~g}$ cat when applicable for all runs except blank. Blank reactor was packed in the same fashion as the typical reactor, replacing the bed of catalyst with a quartz wool plug. Catalyst nomenclature listed in Table 1 of the manuscript. 


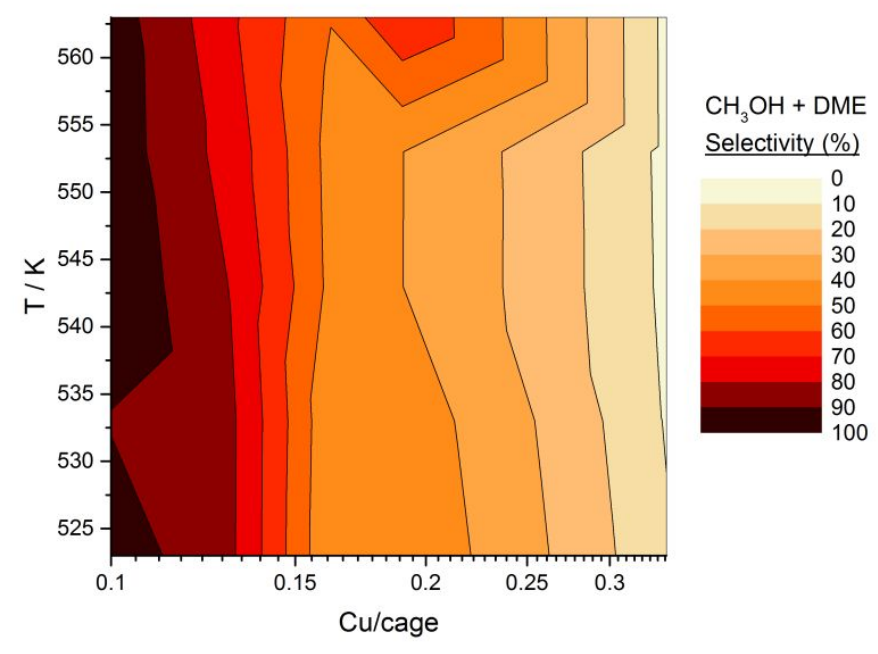

Figure S4. Total $\mathrm{CH}_{3} \mathrm{OH}$ and DME selectivity versus temperature and $\mathrm{Cu}$ loading from kinetic experiments. Reaction conditions were $0.25 \mathrm{~g}$ cat, $25 \mathrm{sccm}, \mathrm{P}_{\mathrm{CH} 4}=18 \mathrm{kPa}, \mathrm{P}_{\mathrm{O} 2}=$ $0.09 \mathrm{kPa}, \mathrm{P}_{\mathrm{H} 2 \mathrm{O}}=3.14 \mathrm{kPa}$, bal $\mathrm{He}$.

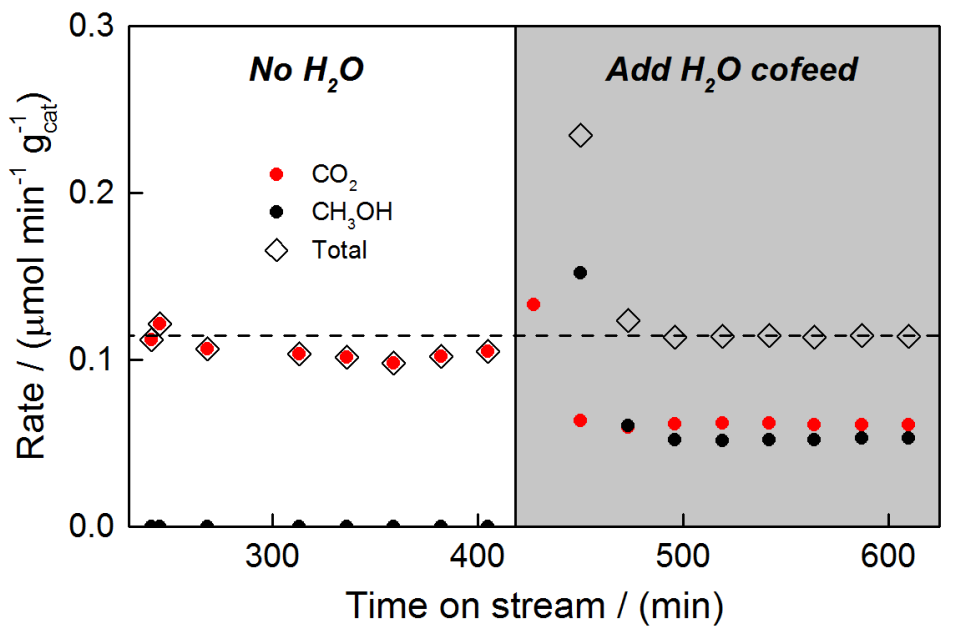

Figure S5. Product formation rates in the absence and presence of $\mathrm{H}_{2} \mathrm{O}$ co-feed. Cu$\mathrm{CHA}(0.23), 0.25 \mathrm{~g}_{\mathrm{cat}}, 543 \mathrm{~K}, 25 \mathrm{sccm}, \mathrm{P}_{\mathrm{CH} 4}=18 \mathrm{kPa}, \mathrm{P}_{\mathrm{O} 2}=0.09 \mathrm{kPa}, \mathrm{P}_{\mathrm{H} 2 \mathrm{O}}=3.14 \mathrm{kPa}$, bal $\mathrm{He}$. In the absence of water, He constituted the makeup gas. 


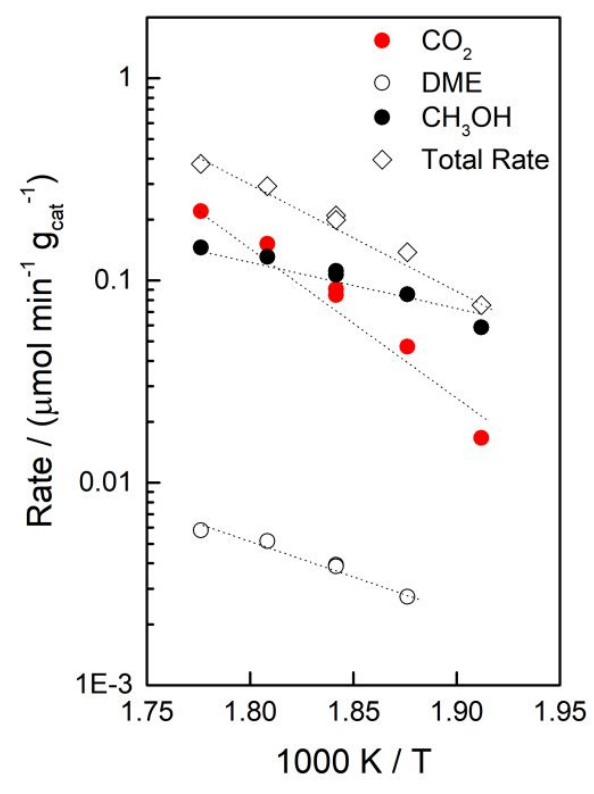

Figure S6. Product formation rates versus temperature. Measured $E_{a}$ was $97 \mathrm{~kJ} \mathrm{~mol}^{-1}$. $\mathrm{Cu}-\mathrm{CHA}(0.11), 0.25 \mathrm{~g}_{\mathrm{cat}}, 523-563 \mathrm{~K}, 25 \mathrm{sccm}, \mathrm{P}_{\mathrm{CH} 4}=18 \mathrm{kPa}, \mathrm{P}_{\mathrm{O} 2}=0.09 \mathrm{kPa}, \mathrm{P}_{\mathrm{H} 2 \mathrm{O}}=3.14$ $\mathrm{kPa}$, bal He. 
A

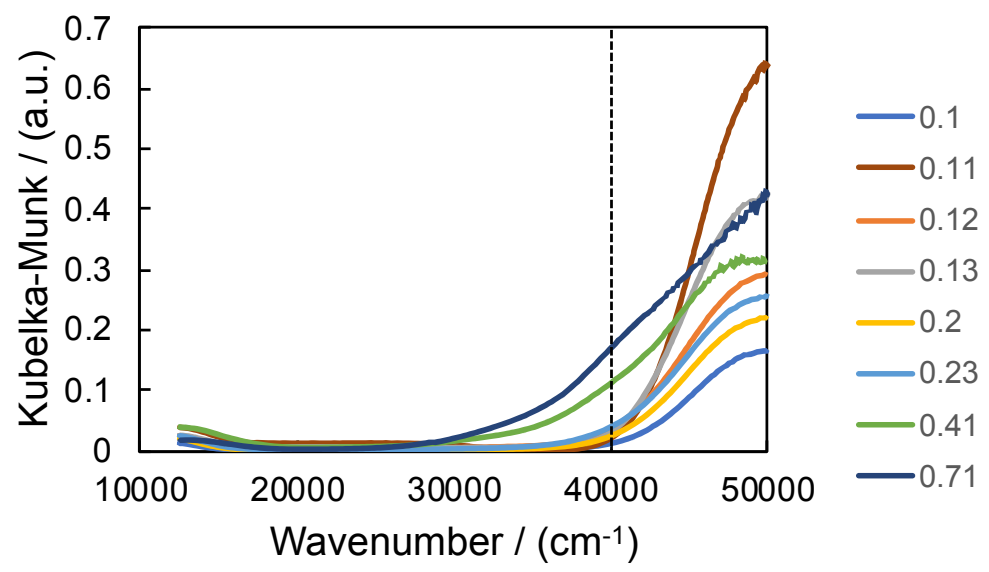

B

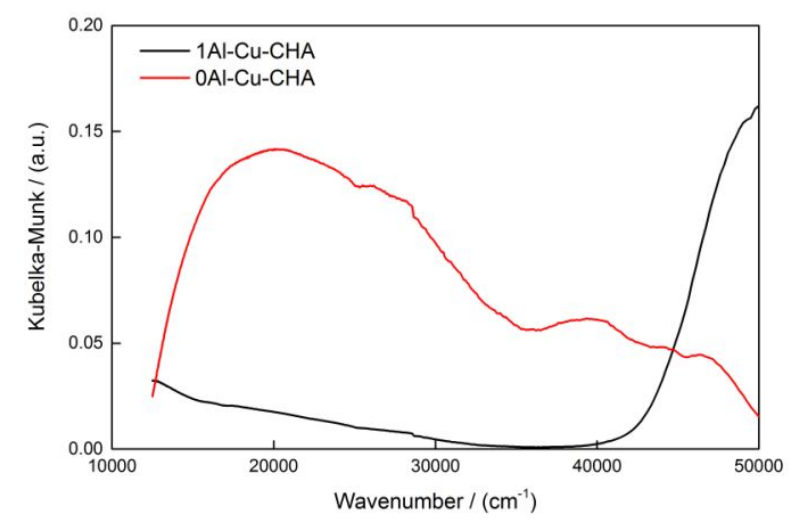

Figure S7. DRUV of Cu-SSZ-13 catalysts at ambient conditions. A. Catalysts with Si/Al $<30$. K-M units normalized to mass loading. Legend refers to $\mathrm{Cu}-\mathrm{CHA}(\mathrm{x})$, where $\mathrm{x}$ is the $\mathrm{Cu} /$ cage as defined in the main text. B. 1Al-Cu-CHA and OAl-Cu-CHA catalysts. The broad $20,000-30,000 \mathrm{~cm}^{-1}$ feature and the feature centered around $40,000 \mathrm{~cm}^{-1}$ for 0Al$\mathrm{Cu}-\mathrm{CHA}$ are consistent with previously reported DRUV of $\mathrm{Cu}_{\mathrm{x}} \mathrm{O}_{\mathrm{y} \cdot} \cdot{ }^{9-11} \mathrm{Cu}-\mathrm{CHA}(0.41)$ and $\mathrm{Cu}-\mathrm{CHA}(0.71)$ display the same $40,000 \mathrm{~cm}^{-1}$ feature consistent with small $\mathrm{CuO}_{\mathrm{x}}$ nanoparticles. 


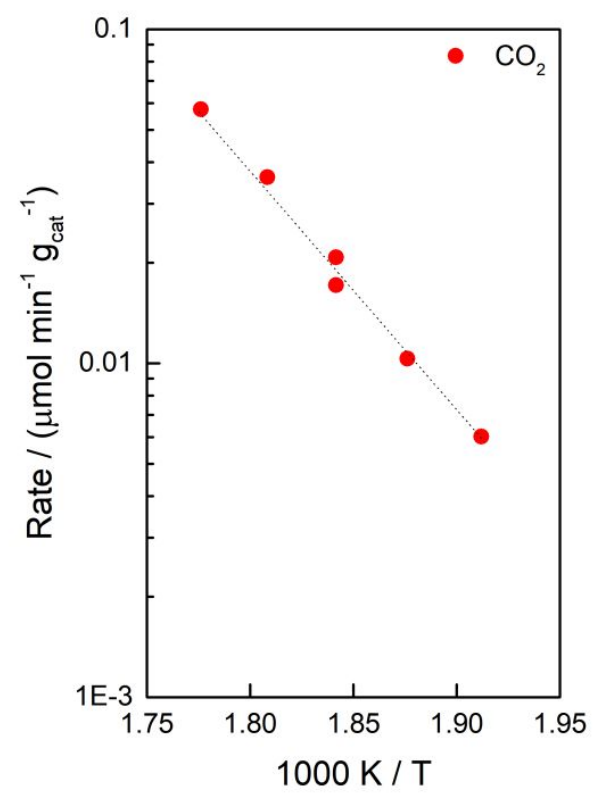

Figure S8. $\mathrm{CO}_{2}$ formation rate versus temperature of $1 \mathrm{wt} \% \mathrm{Cu}_{\mathrm{x}} \mathrm{O}_{\mathrm{y}}$ in defect-free SSZ-13 (OAl-Cu-CHA). $0.21 \mathrm{~g}_{\text {cat }}, 523-563 \mathrm{~K}, 21 \mathrm{sccm}, \mathrm{P}_{\mathrm{CH} 4}=18 \mathrm{kPa}, \mathrm{P}_{\mathrm{O} 2}=0.09 \mathrm{kPa}, \mathrm{P}_{\mathrm{H} 2 \mathrm{O}}=3.14$ $\mathrm{kPa}$, bal He. Calculated apparent activation energy: $\mathrm{E}_{\mathrm{a}}=140 \mathrm{~kJ} \mathrm{~mol}^{-1}$.

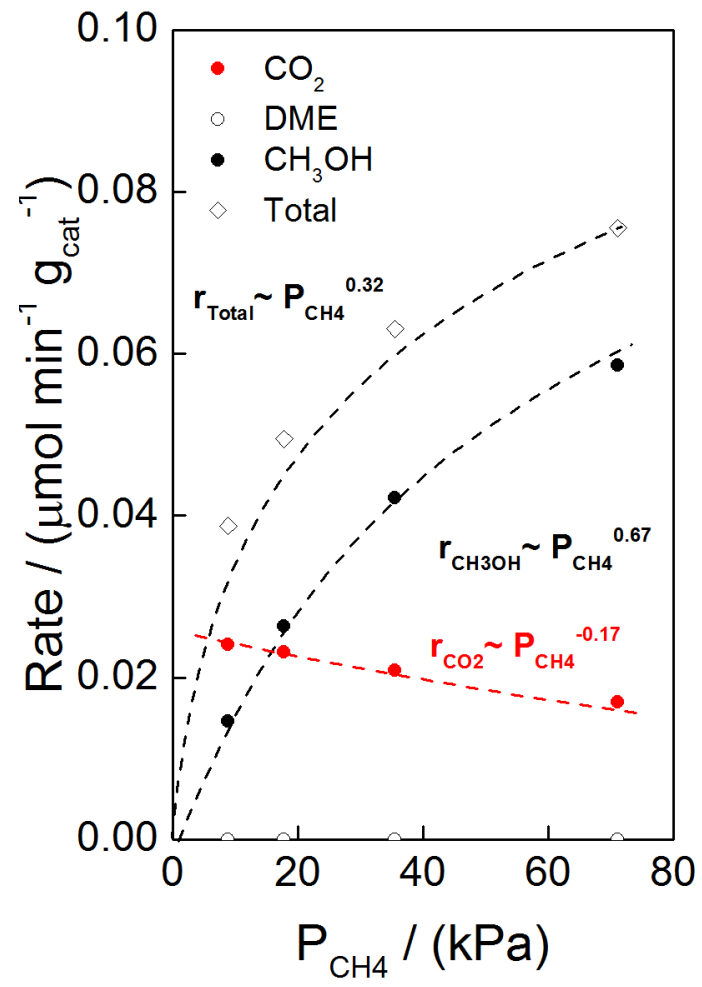

Figure S9. Product formation rates as a function of $\mathrm{CH}_{4}$ partial pressure. 1Al-Cu-CHA, $0.25 \mathrm{~g}_{\mathrm{cat}}, 543 \mathrm{~K}, 25 \mathrm{sccm}, \mathrm{P}_{\mathrm{O} 2}=0.09 \mathrm{kPa}, \mathrm{P}_{\mathrm{H} 2 \mathrm{O}}=3.14 \mathrm{kPa}$, bal He. 


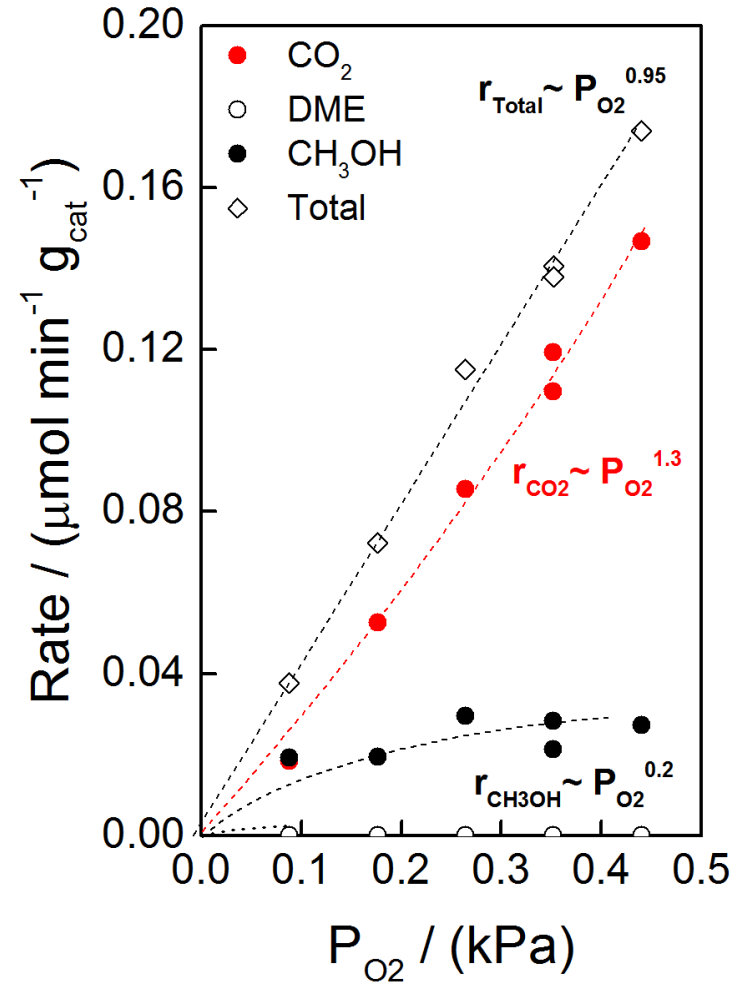

Figure S10. Product formation rates as a function of $\mathrm{O}_{2}$ partial pressure. 1Al-Cu-CHA, $0.25 \mathrm{~g}_{\mathrm{cat}}, 543 \mathrm{~K}, 25 \mathrm{sccm}, \mathrm{P}_{\mathrm{O} 2}=0.09 \mathrm{kPa}, \mathrm{P}_{\mathrm{H} 2 \mathrm{O}}=3.14 \mathrm{kPa}$, bal He. 
Table S2. Reactant order dependencies and apparent activation energies of all catalysts. $0.25 \mathrm{~g}_{\text {cat }}$, baseline conditions were $543 \mathrm{~K}, 25 \mathrm{sccm}, \mathrm{P}_{\mathrm{CH} 4}=18 \mathrm{kPa}, \mathrm{P}_{\mathrm{O} 2}=0.09 \mathrm{kPa}, \mathrm{P}_{\mathrm{H} 2 \mathrm{O}}$ $=3.14 \mathrm{kPa}$, bal He. $\mathrm{E}_{\mathrm{a}}$ was measured from $523-563 \mathrm{~K}$.

\begin{tabular}{|c|c|c|c|c|c|}
\hline \multirow{2}{*}{ Catalyst } & \multirow{2}{*}{$\begin{array}{l}\mathrm{H}^{+} / \text {Cage }^{\mathrm{a}} \\
\operatorname{Max}(\min )\end{array}$} & \multicolumn{3}{|c|}{ Reactant Order Dependency } & \multirow{2}{*}{$\begin{array}{c}E_{a} \\
\left(\mathrm{~kJ} \mathrm{~mol}^{-1}\right)\end{array}$} \\
\hline & & $\mathrm{CH}_{4}$ & $\mathrm{O}_{2}$ & $\mathrm{H}_{2} \mathrm{O}$ & \\
\hline $\mathrm{Cu}-\mathrm{CHA}(0.05)$ & $1.17(1.12)$ & 0.74 & 0 & - & 99 \\
\hline $\mathrm{Cu}-\mathrm{CHA}(0.10)$ & $1.12(1.02)$ & - & - & - & 92 \\
\hline $\mathrm{Cu}-\mathrm{CHA}(0.12)$ & $1.10(0.98)$ & 0.73 & - & - & 99 \\
\hline $\mathrm{Cu}-\mathrm{CHA}(0.20)$ & $1.02(0.82)$ & 0.66 & 0.35 & - & 84 \\
\hline $\mathrm{Cu}-\mathrm{CHA}(0.23)$ & $0.99(0.76)$ & 0.65 & - & - & 92 \\
\hline $\mathrm{Cu}-\mathrm{CHA}(0.42)$ & $0.80(0.38)$ & 0.59 & 0.37 & - & 110 \\
\hline $\mathrm{NH}_{4}-\mathrm{Cu}-\mathrm{CHA}(0.16)$ & $1.09(0)^{\mathrm{b}}$ & $0.82^{\mathrm{d}}$ & 0.2 & - & 100 \\
\hline $\mathrm{Cu}-\mathrm{CHA}(0.11)$ & $0.39(0.28)$ & 0.72 & 0.3 & -0.1 & 97 \\
\hline $\mathrm{Cu}-\mathrm{CHA}(0.04)$ & $0.51(0.47)$ & 0.75 & - & - & 94 \\
\hline $\mathrm{Na}-\mathrm{Cu}-\mathrm{CHA}(0.12)$ & $0.10(0)$ & - & - & - & - \\
\hline $\mathrm{Cu}-\mathrm{CHA}(0.13)$ & $0.87(0.74)$ & - & - & - & 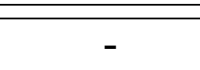 \\
\hline $\mathrm{Cu}-\mathrm{CHA}(0.72)$ & $0.20(0)$ & - & - & - & 128 \\
\hline 1-Al-Cu-CHA & $0.16(0)^{c}$ & 0.32 & 0.95 & - & - \\
\hline OAl-Cu-CHA & $0(0)$ & 0.85 & 0.39 & - & 140 \\
\hline
\end{tabular}

aTheoretical maximum and minimum free $\mathrm{H}+$ content of the zeolite normalized per CHA cage (12 T-sites per cage where a T-site is either a $\mathrm{SiO}_{4}$ or $\mathrm{AlO}_{4}$ tetrahedron). Maximum was calculated assuming every $\mathrm{Cu}$ resides as $\mathrm{Cu}(\mathrm{I})$ and is charge-balancing one $\mathrm{Al}$ T-site, and min was calculated by assuming every $\mathrm{Cu}$ resides as $\mathrm{Cu}(\mathrm{II})$ and is charge-balancing two proximate $\mathrm{Al}$ T-sites.

bMaximum was calculated assuming that $\mathrm{NH}_{3}$ did not bind to any single free proton, and min is assuming that every single free proton has a strongly-bound $\mathrm{NH}_{3}$.

cMaximum was calculated assuming that all $\mathrm{Cu}$ species reside as charge-neutral $\mathrm{CuO}_{\mathrm{x}}$ nanoparticles and do not charge balance any Al T-sites, whereas min was calculated knowing that the number of $\mathrm{Cu}$ atoms exceeds the total framework Al content.

${ }^{\mathrm{d}}$ Reactant order dependences were measured following removal of $\mathrm{NH}_{3}$ from the zeolite. 


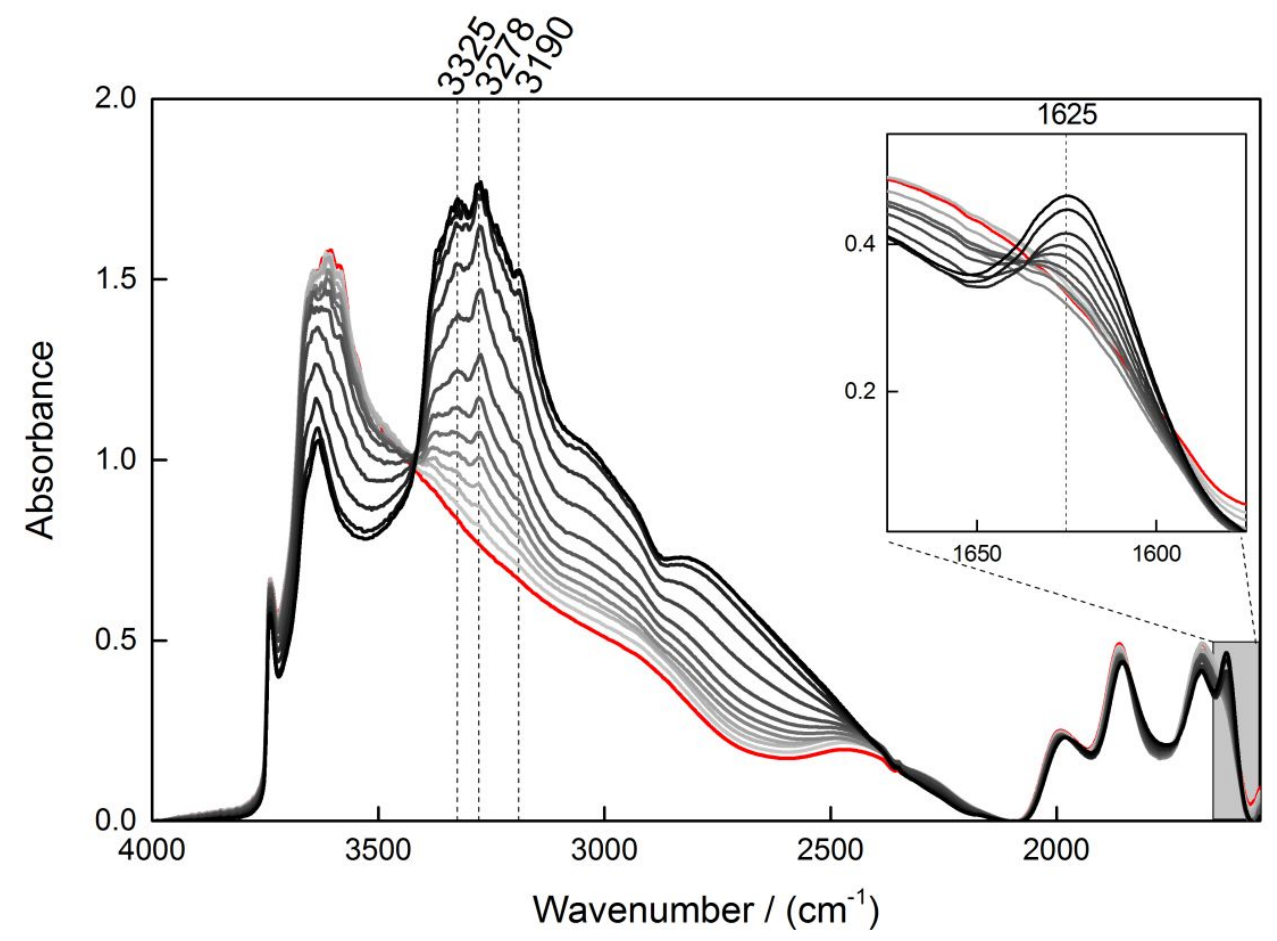

Figure S11. In situ FTIR spectroscopy of $\mathrm{NH}_{3}$ adsorption on $\mathrm{Cu}-\mathrm{CHA}(0.20)$ demonstrating features of $\mathrm{NH}_{3}$ adsorption to $\mathrm{Cu}$ and zeolitic protons. Spectra were collected in transmission of a $10 \mathrm{mg}, 7 \mathrm{~mm}$ self-supporting catalyst wafer at $543 \mathrm{~K}$. Notable spectral features are of $\mathrm{NH}_{3}$ on Brønsted acid sites $\left(3278 \mathrm{~cm}^{-1}\right)$ and $\mathrm{Cu}(3190$ and $\left.1625 \mathrm{~cm}^{-1}\right)^{12-16}$. The feature at $3325 \mathrm{~cm}^{-1}$ has been associated with both $\mathrm{NH}_{3}$ adsorption to Brønsted acid sites and $\mathrm{Cu}$. The $\mathrm{Cu}$ feature at $1625 \mathrm{~cm}^{-1}$ was used for further characterization due to the lack of any overlapping features. 


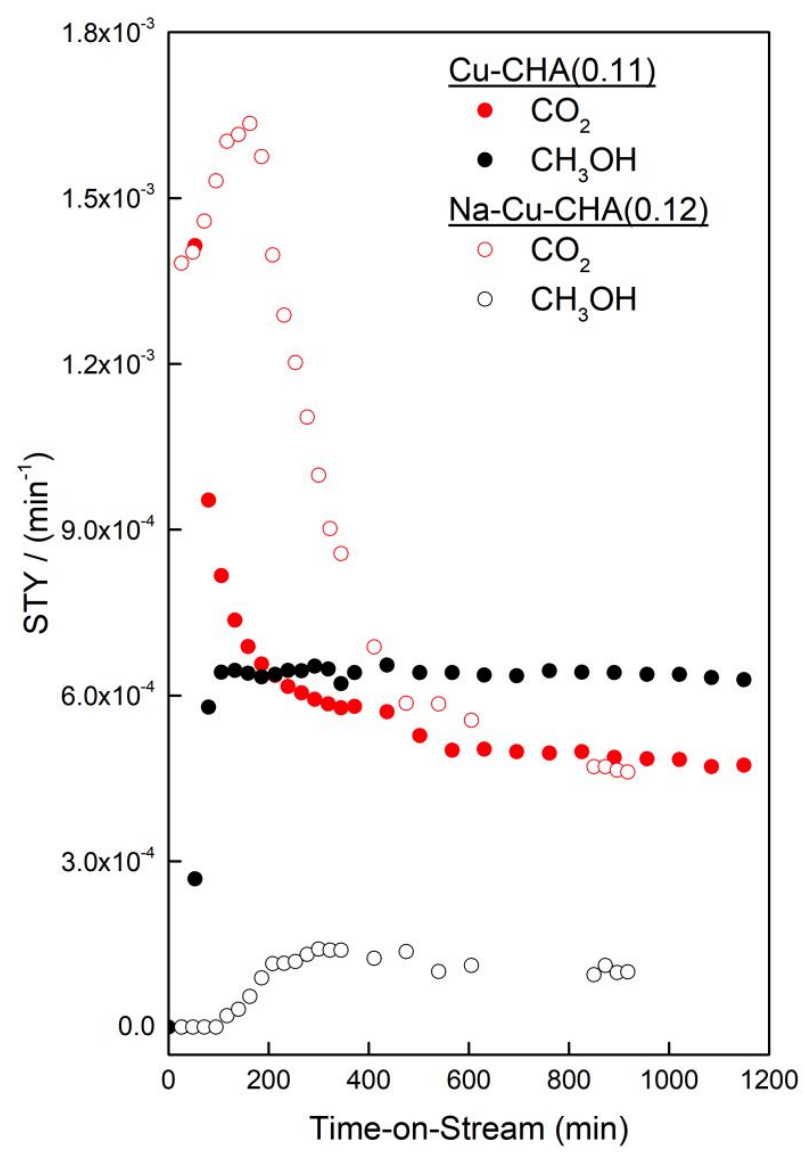

Figure S12. Effect of $\mathrm{Na}$ and removal of Brønsted acidity on $\mathrm{Cu}$-normalized product formation rates. Cu-CHA(0.11), Na-Cu-CHA(0.12), 0.25 gcat, $543 \mathrm{~K}, 25 \mathrm{sccm}, \mathrm{P}_{\mathrm{CH} 4}=18$ $\mathrm{kPa}, \mathrm{P}_{\mathrm{O} 2}=0.09 \mathrm{kPa}, \mathrm{P}_{\mathrm{H} 2 \mathrm{O}}=3.14 \mathrm{kPa}$, bal He . Direct comparison of methane oxidation rates between two zeolites with similar aluminum and $\mathrm{Cu}$ loadings but different proton contents as modified by $\mathrm{Na}^{+}$incorporation demonstrated the rate of methanol formation is markedly reduced. The large fraction of catalytically inactive charge-balancing $\mathrm{Na}^{+}$ions present in Cu-Na-SSZ-13 was partially responsible for the $85 \%$ lower rate of catalytic methanol production, supporting the necessity for Brønsted acidity in the catalytic production of methanol. 

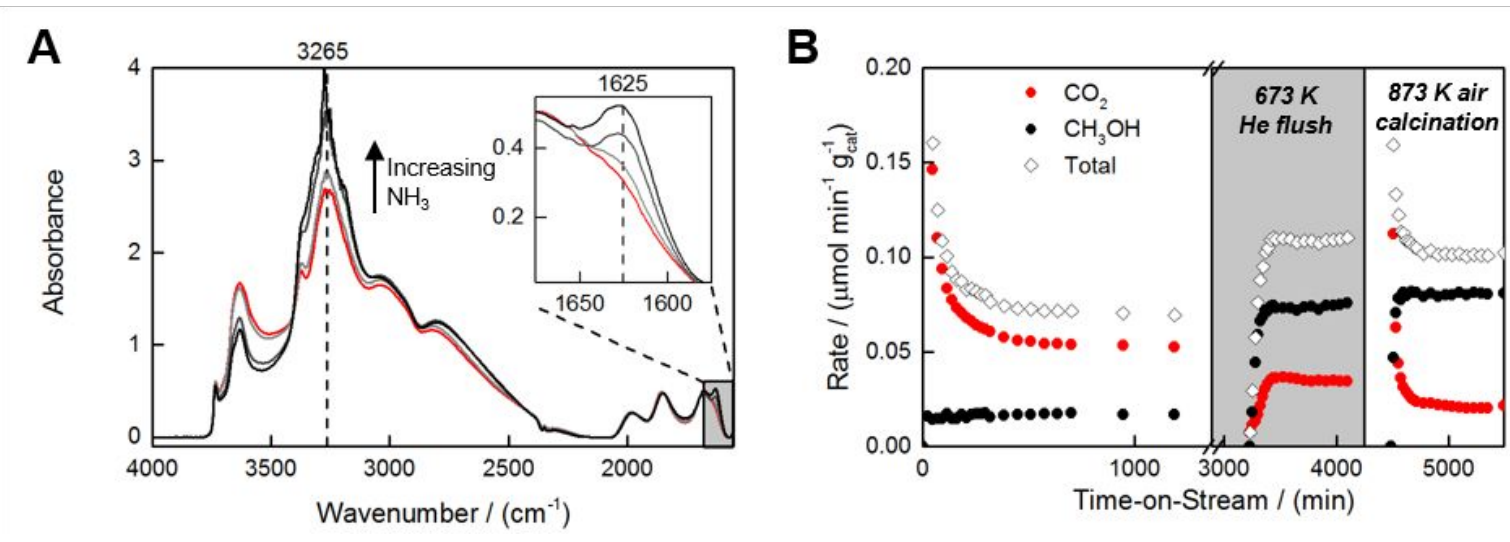

Figure S13. A. In situ FTIR of $\mathrm{NH}_{4}-\mathrm{Cu}-\mathrm{CHA}(0.16)$ B. Product formation rates on $\mathrm{NH}_{4}-\mathrm{Cu}-$ $\mathrm{CHA}(0.16)$ and after desorption of $\mathrm{NH}_{3}$ from Brønsted acid sites (middle and right). Methane activation conditions were $0.25 \mathrm{~g}_{\mathrm{cat}}, 543 \mathrm{~K}, 25 \mathrm{sccm}, \mathrm{P}_{\mathrm{CH} 4}=18 \mathrm{kPa}, \mathrm{P}_{\mathrm{O} 2}=0.09$ $\mathrm{kPa}, \mathrm{P}_{\mathrm{H} 2 \mathrm{O}}=3.14 \mathrm{kPa}$, bal He. $\mathrm{P}_{\mathrm{NH} 3}=0.8 \mathrm{kPa}$ when co-feeding $\mathrm{NH}_{3}$. Spectra were collected in transmission of a $10 \mathrm{mg}, 7 \mathrm{~mm}$ self-supporting catalyst wafer at $543 \mathrm{~K}$. FTIR analysis showed that the $\mathrm{NH}_{4}{ }^{+}$features of the as-synthesized catalyst were significant, whereas the $\mathrm{Cu}-\mathrm{NH}_{3}$ features were nonexistent. Subsequent $\mathrm{NH}_{3}$ dosing moderately increased the $\mathrm{NH}_{4}{ }^{+}$features, demonstrating the presence of some Brønsted acid sites either due to incomplete $\mathrm{NH}_{3}$ exchange or partial desorption during $\mathrm{Cu}$-ion exchange or FTIR experimentation. This catalyst facilitated $\mathrm{C}-\mathrm{H}$ activation with a nearly $75 \%$ selectivity towards $\mathrm{CO}_{2}$ formation. Treating the catalyst with a $673 \mathrm{~K}$ purge of helium resulted in a nearly $50 \%$ increase in the total rate of $\mathrm{C}-\mathrm{H}$ activation and a shift in selectivity towards methanol and away from complete $\mathrm{CH}_{4}$ oxidation. 
A

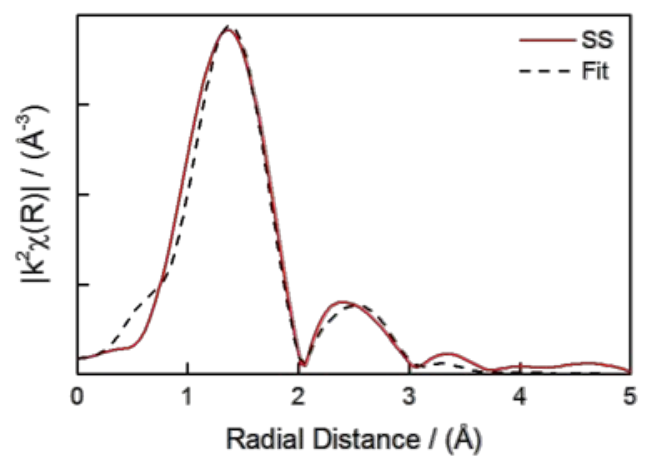

B

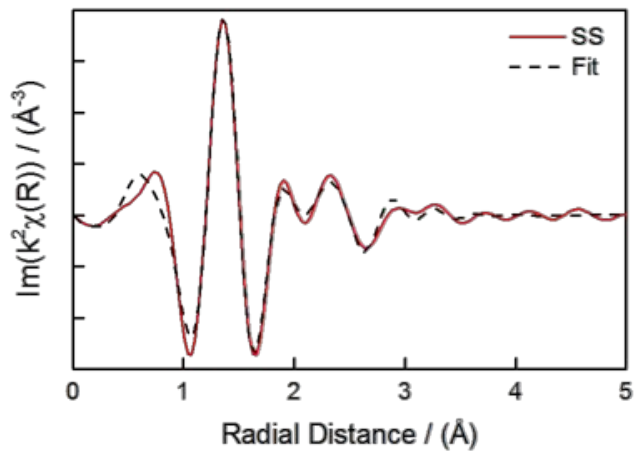

C

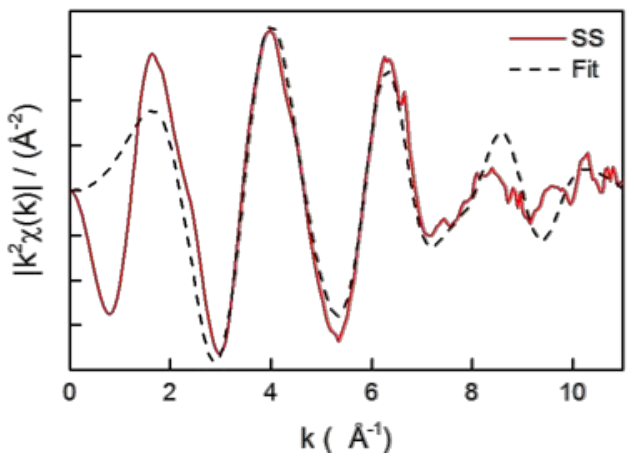

Figure S14. EXAFS fitting of $\mathrm{Cu}-\mathrm{CHA}(0.11)$ upon exposure to methanol synthesis flows at $543 \mathrm{~K}$ of $\mathrm{P}_{\mathrm{CH} 4}=18 \mathrm{kPa}, \mathrm{P}_{\mathrm{O} 2}=0.09 \mathrm{kPa}, \mathrm{P}_{\mathrm{H} 2 \mathrm{O}}=3.14 \mathrm{kPa}$, bal He. A. Magnitude and $\mathbf{B}$. Imaginary part of $\mathrm{k}^{2}$ weighted Fourier transform $\mathbf{C}$. Raw EXAFS spectrum with fit with $\mathrm{k}^{2}$ weight 
Table S3. EXAFS fitting results of Cu-CHA(0.11) under methanol synthesis and $\mathrm{NH}_{3}$ flows. All spectra were collected at $543 \mathrm{~K}$. The catalyst was pretreated in $1 \mathrm{kPa} \mathrm{O}_{2}$, bal $\mathrm{He}$ from room temperature to $543 \mathrm{~K}$ at $5 \mathrm{~K} \mathrm{~min}^{-1}$. At $543 \mathrm{~K}$, the catalyst was exposed to methanol synthesis flows of $\mathrm{P}_{\mathrm{CH} 4}=18 \mathrm{kPa}, \mathrm{P}_{\mathrm{O} 2}=0.09 \mathrm{kPa}, \mathrm{P}_{\mathrm{H} 2 \mathrm{O}}=3.14 \mathrm{kPa}$, bal He, an additional $\mathrm{NH}_{3}$ co-feed of $\mathrm{P}_{\mathrm{NH} 3}=1.6 \mathrm{kPa}$, and then the removal of $\mathrm{NH}_{3}$. Following $\mathrm{NH}_{3}$ removal, the catalyst was brought to $673 \mathrm{~K}$ at $6 \mathrm{~K} \mathrm{~min}^{-1}$ and held in dry He before cooling to $543 \mathrm{~K}$ and exposure to methanol synthesis flows. An amplitude factor of 0.86 was obtained by fitting a $\mathrm{Cu}$ foil reference. The range of fitting provided 7 independent points. Initial fits were obtained by fitting one $\sigma^{2}$ value for both scattering fits and then optimized by increasing $\sigma^{2}$ Cu-Cu to minimize the $\mathrm{R}$-factor. These values are similar to those reported by Pappas et al. ${ }^{17}$ Correlations between $\Delta \mathrm{R}_{\mathrm{Cu}-\mathrm{O}}$ and $\Delta \mathrm{E}$ and $\sigma^{2} \mathrm{Cu-O}$ and $\mathrm{N}_{\mathrm{Cu}-\mathrm{O}}$ were 0.93 . All others were less than 0.6.

\begin{tabular}{|c|c|c|c|c|c|c|c|c|}
\hline $\begin{array}{c}\text { Gas } \\
\text { Treatment }\end{array}$ & $\mathbf{N}_{\text {Cu-O }}$ & $\mathbf{R}_{\text {Cu-o }}(\boldsymbol{A})$ & $\mathbf{N}_{\mathrm{Cu}-\mathrm{Cu}}$ & $\mathbf{R}_{\mathrm{Cu}-\mathrm{Cu}}(\boldsymbol{\AA})$ & $\Delta E(e V)$ & $\sigma^{2} \mathrm{Cu-O}$ & $\sigma^{2} \mathrm{Cu}-\mathrm{Cu}$ & R-factor \\
\hline Pretreatment & $\begin{array}{r}2.9 \\
\pm 0.9\end{array}$ & $\begin{array}{c}1.90 \\
\pm 0.02\end{array}$ & $\begin{array}{c}1.6 \\
\pm 0.6\end{array}$ & $\begin{array}{c}2.94 \\
\pm 0.04\end{array}$ & $\begin{array}{l}-7 \\
\pm 3\end{array}$ & $\begin{array}{c}0.004 \\
\pm 0.004\end{array}$ & 0.01 & 0.007 \\
\hline Steady State & $\begin{array}{r}3.1 \\
\pm 1.1\end{array}$ & $\begin{array}{c}1.92 \\
\pm 0.03 \\
\end{array}$ & $\begin{array}{c}1.1 \\
\pm 0.6\end{array}$ & $\begin{array}{c}2.94 \\
\pm 0.05\end{array}$ & $\begin{array}{l}-6 \\
\pm 4\end{array}$ & $\begin{array}{c}0.006 \\
\pm 0.005 \\
\end{array}$ & 0.01 & 0.008 \\
\hline $\begin{array}{c}\text { Steady State } \\
+\mathrm{NH}_{3}\end{array}$ & $\begin{array}{c}1.8 \\
\pm 0.3\end{array}$ & $\begin{array}{c}1.90 \\
\pm 0.01\end{array}$ & - & - & $\begin{array}{l}-4 \\
\pm 2\end{array}$ & $\begin{array}{c}0.004 \\
\pm 0.003\end{array}$ & - & 0.003 \\
\hline $\begin{array}{l}\text { Steady State } \\
\text { post- } \mathrm{NH}_{3}\end{array}$ & $\begin{array}{c}2.5 \\
\pm 0.4\end{array}$ & $\begin{array}{c}1.90 \\
\pm 0.02\end{array}$ & $\begin{array}{c}0.5 \\
\pm 0.2\end{array}$ & $\begin{array}{c}2.96 \\
\pm 0.03\end{array}$ & $\begin{array}{l}-5 \\
\pm 2\end{array}$ & $\begin{array}{c}0.006 \\
\pm 0.002\end{array}$ & 0.006 & 0.004 \\
\hline $\begin{array}{l}\text { Steady State } \\
\text { post-purge }\end{array}$ & $\begin{array}{r}3.0 \\
\pm 0.8\end{array}$ & $\begin{array}{c}1.91 \\
\pm 0.05\end{array}$ & $\begin{array}{l}1.7 \\
\pm 0.7\end{array}$ & $\begin{array}{c}2.96 \\
\pm 0.04\end{array}$ & $\begin{array}{l}-7 \\
\pm 3\end{array}$ & $\begin{array}{c}0.004 \\
\pm 0.003\end{array}$ & 0.015 & 0.004 \\
\hline
\end{tabular}

Table S4. EXAFS fitting results of $\mathrm{Cu}-\mathrm{CHA}(0.11)$ under methanol synthesis flows and fitting the second shell with a $\mathrm{Cu}$-T-site scattering path. An unphysical $\mathrm{CN}$ was obtained for the Cu-T-site scattering path.

\begin{tabular}{c|ccccccc}
\hline $\begin{array}{c}\text { Gas } \\
\text { Treatment }\end{array}$ & $\mathbf{N}_{\text {Cu-o }}$ & $\mathbf{R}_{\text {Cu-o }}(\AA)$ & $\mathbf{N}_{\text {Cu-T }}$ & $\mathbf{R}_{\text {Cu-T }}(\AA)$ & $\begin{array}{c}\Delta E \\
(\mathbf{e V})\end{array}$ & $\boldsymbol{\sigma}^{2}$ & R-factor \\
\hline Steady State & $2.9 \pm 0.6$ & $1.93 \pm 0.01$ & $\mathbf{- 1 . 1 \pm 0 . 4}$ & $3.00 \pm 0.03$ & $-4 \pm 2$ & $0.006 \pm 0.003$ & 0.003 \\
\hline
\end{tabular}


Table S4. EXAFS fitting results of $1 \mathrm{Al}-\mathrm{Cu}-\mathrm{CHA}$ under methanol synthesis and $\mathrm{NH}_{3}$ flows. All spectra were collected at $543 \mathrm{~K}$. EXAFS was fit from $\mathrm{k}=3$ to $\sim 10.5 \AA^{-1}$ and $\mathrm{R}=1.45$ $-3 \AA$. The catalyst was pretreated in $1 \mathrm{kPa} \mathrm{O}$, bal He from room temperature to $543 \mathrm{~K}$ at $5 \mathrm{~K} \mathrm{~min}^{-1}$. At $543 \mathrm{~K}$, the catalyst was exposed to methanol synthesis flows of $\mathrm{P}_{\mathrm{CH} 4}=18$ $\mathrm{kPa}, \mathrm{P}_{\mathrm{O} 2}=0.09 \mathrm{kPa}, \mathrm{P}_{\mathrm{H} 2 \mathrm{O}}=3.14 \mathrm{kPa}$, bal He, and an additional $\mathrm{NH}_{3}$ co-feed of $\mathrm{P}_{\mathrm{NH} 3}=$ $1.6 \mathrm{kPa}$. An amplitude factor of 0.83 was obtained by fitting a $\mathrm{Cu}$ foil reference. The range of fitting provided 8 independent points. Initial fits were obtained by fitting one $\sigma^{2}$ value for both scattering fits and then optimized by increasing $\sigma^{2} \mathrm{Cu}-\mathrm{Cu}$ to minimize the R-factor. These values are similar to those reported by Pappas et al. ${ }^{17}$ Correlations between $\Delta R_{\text {Cu- }}$ $\mathrm{Cu}$ and $\Delta \mathrm{E}_{\mathrm{Cu}-\mathrm{Cu}}, \Delta \mathrm{R}_{\mathrm{Cu}-\mathrm{O}}$ and $\Delta \mathrm{E}_{\mathrm{Cu}-\mathrm{O}}$, and $\sigma^{2} \mathrm{Cu-O}$ and $\mathrm{N}_{\mathrm{Cu}-\mathrm{O}}$ were $0.93,0.91$, and 0.87 , respectively. All others were less than 0.6.

\begin{tabular}{|c|c|c|c|c|c|c|c|c|c|}
\hline $\begin{array}{c}\text { Gas } \\
\text { Treatment }\end{array}$ & $\mathbf{N}_{\text {Cu-O }}$ & $\mathbf{R}_{\mathrm{Cu}-\mathrm{o}}(\mathbf{A})$ & $\mathbf{N}_{\mathrm{Cu}-\mathrm{Cu}}$ & $\mathbf{R}_{\mathrm{Cu}-\mathrm{Cu}}(\mathbf{A})$ & $\begin{array}{c}\Delta E_{\text {Cu-o }} \\
(e V)\end{array}$ & $\begin{array}{c}\Delta E_{\mathrm{Cu}-\mathrm{Cu}} \\
(\mathrm{eV})\end{array}$ & $\sigma^{2} \mathrm{Cu}-\mathrm{O}$ & $\sigma^{2} \mathrm{Cu}-\mathrm{Cu}$ & R-factor \\
\hline Steady State & $\begin{array}{c}1.8 \\
\pm 0.5\end{array}$ & $\begin{array}{c}1.94 \\
\pm 0.02\end{array}$ & $\begin{array}{c}0.6 \\
\pm 0.3\end{array}$ & $\begin{array}{c}2.9 \\
\pm 0.1\end{array}$ & $\begin{array}{c}1 \\
\pm 3\end{array}$ & $\begin{array}{c}-8 \\
\pm 15\end{array}$ & $\begin{array}{r}0.002 \\
\pm 0.003\end{array}$ & 0.008 & 0.011 \\
\hline $\begin{array}{c}\text { Steady State } \\
+\mathrm{NH}_{3}\end{array}$ & $\begin{array}{r}1.6 \\
+0.8 \\
\end{array}$ & $\begin{array}{r}1.93 \\
\pm 0.04 \\
\end{array}$ & - & . & $\begin{array}{r}0.3 \\
\pm 5 \\
\end{array}$ & _ & $\begin{array}{r}0.003 \\
\pm 0.005 \\
\end{array}$ & - & 0.012 \\
\hline
\end{tabular}

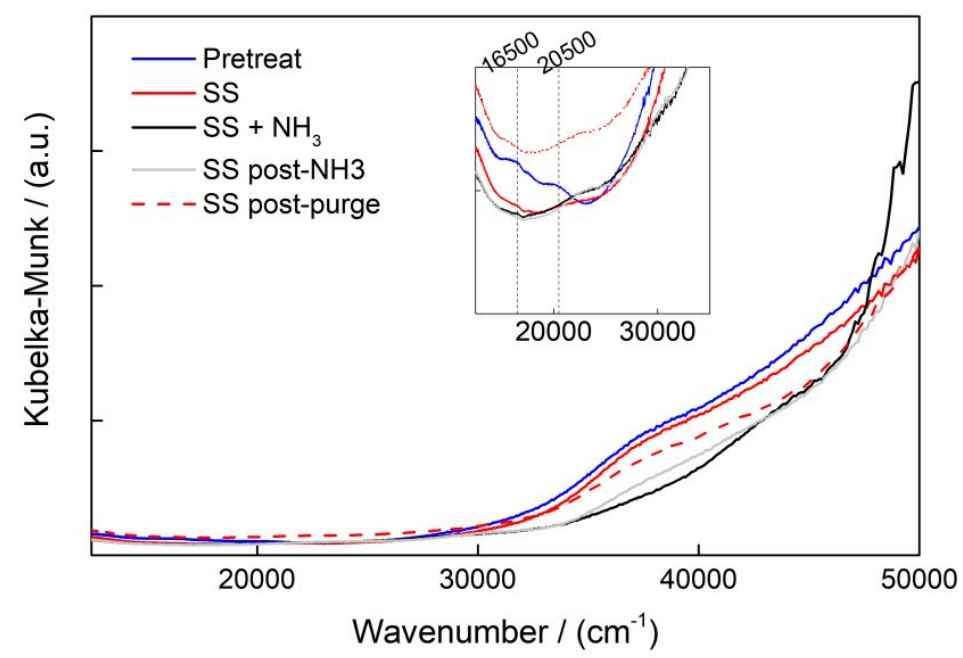

Figure S15. In situ DRUV of Cu-CHA(0.11). All spectra were collected at $543 \mathrm{~K}$ and $\mathrm{H}-$ $\mathrm{SSZ}-13(\mathrm{Si} / \mathrm{Al}=15)$ was used as a baseline. Evidence of $\mathrm{Cu}$ dimer motifs were not observed at $22,700 \mathrm{~cm}^{-1}$. The band at $37,500 \mathrm{~cm}^{-1}$ can be associated with Cu dimers ${ }^{18}$ or simply the ligand-metal charge-transfer of $\mathrm{Cu}^{2+} .{ }^{19}$ The catalyst was pretreated in $1 \mathrm{kPa}$ $\mathrm{O}_{2}$, bal He from room temperature to $543 \mathrm{~K}$ at $5 \mathrm{~K} \mathrm{~min}^{-1}$ (Pretreat). At $543 \mathrm{~K}$, the catalyst was exposed to methanol synthesis flows of $\mathrm{P}_{\mathrm{CH} 4}=18 \mathrm{kPa}, \mathrm{P}_{\mathrm{O} 2}=0.09 \mathrm{kPa}, \mathrm{P}_{\mathrm{H} 2 \mathrm{O}}=3.14$ $\mathrm{kPa}$, bal $\mathrm{He}(\mathrm{SS})$, an additional $\mathrm{NH}_{3}$ co-feed of $\mathrm{P}_{\mathrm{NH} 3}=1.6 \mathrm{kPa}\left(\mathrm{SS}+\mathrm{NH}_{3}\right)$, and then the removal of $\mathrm{NH}_{3}$ (SS post- $\mathrm{NH}_{3}$ ). Following $\mathrm{NH}_{3}$ removal, the catalyst was brought to 673 $\mathrm{K}$ at $6 \mathrm{~K} \mathrm{~min}^{-1}$ and held in dry He before cooling to $543 \mathrm{~K}$ and exposure to methanol synthesis flows (SS post-purge). 
A

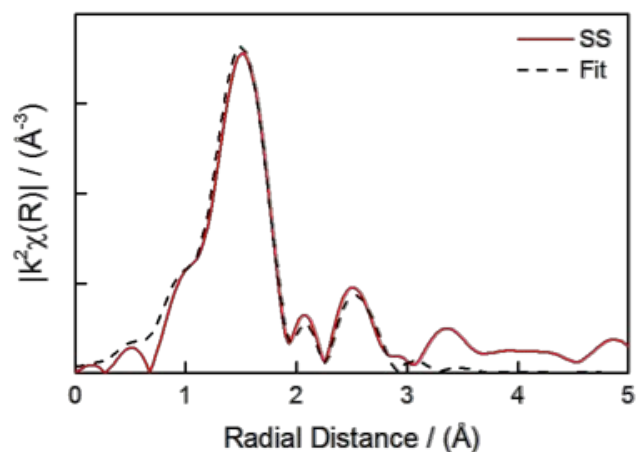

B

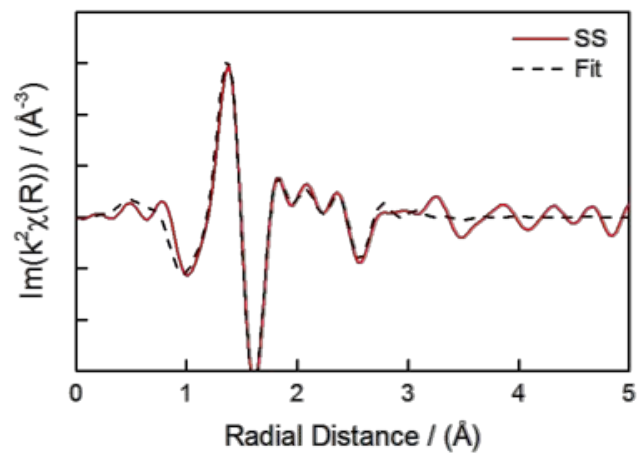

C

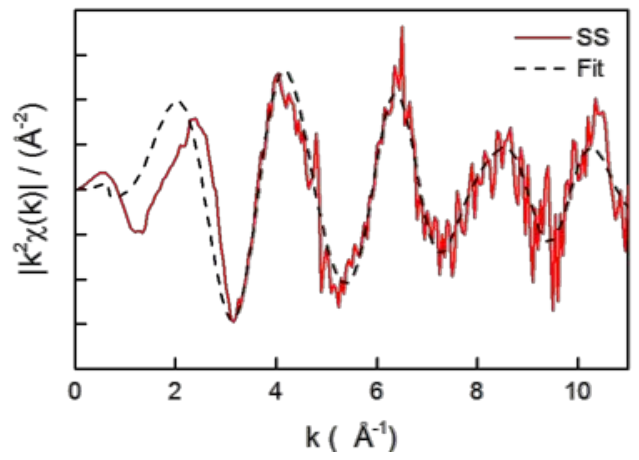

Figure S16. EXAFS fitting of $1 \mathrm{Al}-\mathrm{Cu}-\mathrm{CHA}$ upon exposure to methanol synthesis flows at $543 \mathrm{~K}$ of $\mathrm{P}_{\mathrm{CH} 4}=18 \mathrm{kPa}, \mathrm{P}_{\mathrm{O} 2}=0.09 \mathrm{kPa}, \mathrm{P}_{\mathrm{H} 2 \mathrm{O}}=3.14 \mathrm{kPa}$, bal He. A. Magnitude and $\mathbf{B}$. Imaginary part of $\mathrm{k}^{2}$ weighted Fourier transform $\mathbf{C}$. Raw EXAFS spectrum with fit with $\mathrm{k}^{2}$ weight 


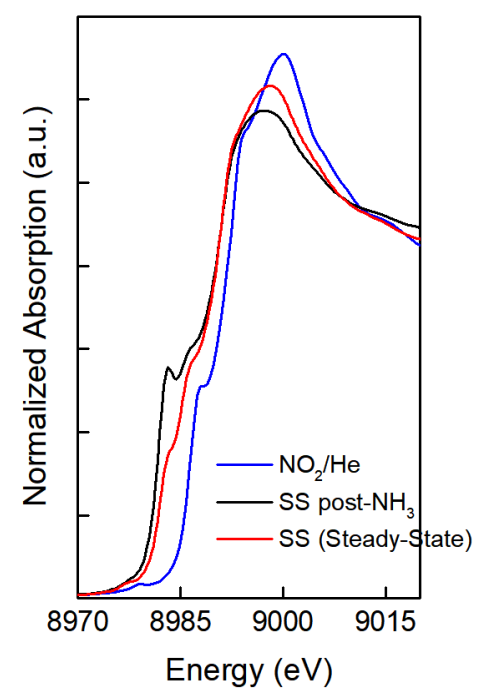

Figure S17. $\mathrm{Cu} X A N E S$ of $\mathrm{Cu}-\mathrm{CHA}(0.11)$ following exposure to $\mathrm{NO}_{2}$ and $\mathrm{O}_{2} .1 \mathrm{kPa} \mathrm{NO}$, bal He exposure followed exposure to a $1 \mathrm{kPa} \mathrm{NH}_{3}, 1 \mathrm{kPa} \mathrm{NO}$, bal He gas treatment at $493 \mathrm{~K}$. As described previously, the $1 \mathrm{kPa} \mathrm{NH}_{3}, 1 \mathrm{kPa} \mathrm{NO}$, bal He, $493 \mathrm{~K}$ treatment resulted in entirely isolated $\mathrm{Cu}(\mathrm{I})$ species. $\mathrm{No} \mathrm{Cu}(\mathrm{I})$ pre-edge feature $(8983 \mathrm{eV})$ is evident upon exposure to $1 \mathrm{kPa} \mathrm{NO}$, bal He. At $543 \mathrm{~K}$, the catalyst was exposed to methanol synthesis flows of $\mathrm{P}_{\mathrm{CH} 4}=18 \mathrm{kPa}, \mathrm{P}_{\mathrm{O} 2}=0.09 \mathrm{kPa}, \mathrm{P}_{\mathrm{H} 2 \mathrm{O}}=3.14 \mathrm{kPa}$, bal $\mathrm{He}(\mathrm{SS})$, an additional $\mathrm{NH}_{3}$ co-feed of $\mathrm{P}_{\mathrm{NH} 3}=1.6 \mathrm{kPa}$, and then the removal of $\mathrm{NH}_{3}\left(\mathrm{SS}\right.$ post $\left.-\mathrm{NH}_{3}\right)$. $\mathrm{Cu}(\mathrm{I})$ persists upon exposure to dilute $\mathrm{O}_{2}$. 


\section{References}

1. Di lorio, J. R.; Gounder, R., Controlling the Isolation and Pairing of Aluminum in Chabazite Zeolites Using Mixtures of Organic and Inorganic Structure-Directing Agents. Chem. Mater. 2016, 28 (7), 2236-2247.

2. Martínez-Franco, R.; Moliner, M.; Thogersen, J. R.; Corma, A., Efficient One-Pot Preparation of Cu-SSZ-13 Materials using Cooperative OSDAs for their Catalytic Application in the SCR of NOx. ChemCatChem 2013, 5 (11), 3316-3323.

3. Ren, L.; Zhu, L.; Yang, C.; Chen, Y.; Sun, Q.; Zhang, H.; Li, C.; Nawaz, F.; Meng, X.; Xiao, F.-S., Designed copper-amine complex as an efficient template for one-pot synthesis of Cu-SSZ-13 zeolite with excellent activity for selective catalytic reduction of NOx by NH3. Chem. Commun. 2011, 47 (35), 9789-9791.

4. $\quad$ Eilertsen, E. A.; Arstad, B.; Svelle, S.; Lillerud, K. P., Single parameter synthesis of high silica CHA zeolites from fluoride media. Microporous Mesoporous Mater. 2012, 153, 94-99.

5. Díaz-Cabañas, M.-J.; A. Barrett, P., Synthesis and structure of pure SiO2 chabazite: the $\mathrm{SiO} 2$ polymorph with the lowest framework density. Chem. Commun. 1998, (17), 1881-1882.

6. Baerlocher, C.; McCusker, L. B., Database of Zeolite Structures. 1996.

7. Center, P. C.; Company, D. C. GraidentCheck for Heterogeneous Catalysis, 0.95; West Lafayette, Indiana, 2016.

8. Technology, N. I. o. S. a., NIST Chemistry WebBook: NIST Standard Reference Database Number 69. U.S. Department of Commerce: Washington, D.C., 2018.

9. Tandon, S. P.; Gupta, J. P., Diffuse Reflectance Spectrum of Cupric Oxide. Spectrosc. Lett. 1969, 2 (12), 357-360.

10. Tandon, S. P.; Gupta, J. P., Diffuse Reflectance Spectrum of Cuprous Oxide. physica status solidi (b) 1970, 37 (1), 43-45.

11. Alswat, A. A.; Ahmad, M. B.; Hussein, M. Z.; Ibrahim, N. A.; Saleh, T. A., Copper oxide nanoparticles-loaded zeolite and its characteristics and antibacterial activities. Journal of Materials Science \& Technology 2017, 33 (8), 889-896.

12. Ma, L.; Cheng, Y.; Cavataio, G.; McCabe, R. W.; Fu, L.; Li, J., In situ DRIFTS and temperature-programmed technology study on NH3-SCR of NOx over Cu-SSZ-13 and Cu-SAPO-34 catalysts. Appl. Catal., B 2014, 156-157, 428-437.

13. Lezcano-Gonzalez, I.; Deka, U.; Arstad, B.; Van Yperen-De Deyne, A.; Hemelsoet, K.; Waroquier, M.; Van Speybroeck, V.; Weckhuysen, B. M.; Beale, A. M., Determining the storage, availability and reactivity of $\mathrm{NH} 3$ within $\mathrm{Cu}$-Chabazite-based Ammonia Selective Catalytic Reduction systems. PCCP 2014, 16 (4), 1639-1650.

14. Zhu, H.; Kwak, J. H.; Peden, C. H.; Szanyi, J., In situ DRIFTS-MS studies on the oxidation of adsorbed NH3 by NOx over a Cu-SSZ-13 zeolite. Catal. Today 2013, 205, 16-23.

15. Giordanino, F.; Vennestrom, P. N.; Lundegaard, L. F.; Stappen, F. N.; Mossin, S.; Beato, P.; Bordiga, S.; Lamberti, C., Characterization of Cu-exchanged SSZ-13: a comparative FTIR, UV-Vis, and EPR study with Cu-ZSM-5 and Cu-beta with similar Si/Al and Cu/Al ratios. Dalton Trans. 2013, 42 (35), 12741-61.

16. Szanyi, J.; Kwak, J. H.; Zhu, H.; Peden, C. H., Characterization of Cu-SSZ-13 NH3 SCR catalysts: an in situ FTIR study. PCCP 2013, 15 (7), 2368-2380. 
17. Pappas, D. K.; Borfecchia, E.; Dyballa, M.; Pankin, I. A.; Lomachenko, K. A.; Martini, A.; Signorile, M.; Teketel, S.; Arstad, B.; Berlier, G.; Lamberti, C.; Bordiga, S.; Olsbye, U.; Lillerud, K. P.; Svelle, S.; Beato, P., Methane to Methanol: Structure-Activity Relationships for Cu-CHA. J. Am. Chem. Soc. 2017, 139 (42), 14961-14975.

18. Li, H.; Paolucci, C.; Khurana, I.; Wilcox, Laura N.; Göltl, F.; Albarracin-Caballero, J. D.; Shih, A. J.; Ribeiro, F. H.; Gounder, R.; Schneider, W. F., Consequences of exchange-site heterogeneity and dynamics on the UV-visible spectrum of Cu-exchanged SSZ-13. Chemical Science 2019, 10 (8), 2373-2384.

19. Ipek, B.; Wulfers, M. J.; Kim, H.; Göltl, F.; Hermans, I.; Smith, J. P.; Booksh, K. S.; Brown, C. M.; Lobo, R. F., Formation of [Cu2O2]2+ and [Cu2O]2+ toward C-H Bond Activation in Cu-SSZ-13 and Cu-SSZ-39. ACS Catal. 2017, 7 (7), 4291-4303. 